\title{
Episyenites-Characteristics, Genetic Constraints, and Mineral Potential
}

\author{
E. Suikkanen ${ }^{1}$ (D) - O. T. Rämö ${ }^{1}$
}

Received: 6 March 2019 / Accepted: 22 July 2019 / Published online: 7 August 2019

(C) The Author(s) 2019

\begin{abstract}
Episyenites are sub-solidus, quartz-depleted alkali-feldspar-rich rocks. They form veins and lenticular bodies in granitoid rocks and migmatites in a late- to post-orogenic or anorogenic setting. Leaching of quartz is usually a response to a flux of weakly saline hydrothermal solution in circulation cells above cooling intrusions, where sufficient fluid-rock ratios and thermal gradients are achieved. Fluid Si-undersaturation is achieved by rapid cooling within the field of retrograde Si solubility or by temperature and pressure increase outside retrograde conditions. Some quartz may also be consumed in metasomatic reactions and in response to pressure fluctuation in sealed episyenite bodies. The small size and overall rarity of episyenites imply that conditions for episyenite formation are not commonly encountered in the crust. In addition to quartz depletion, episyenites record complex histories of metasomatic alteration and hydrothermal mineral growth. Nearly all episyenites have undergone Na-metasomatism, which may have led to the formation of nearly monomineralic albitite, and which is occasionally followed by late K-metasomatism, phyllic alteration, and argillization. Depending on the effectiveness of later compaction, recrystallization and vug-filling episyenites may preserve the macroscopic porosity formed by quartz dissolution and brittle deformation. Vuggy episyenites can act as significant sinks for metals carried by crustal fluids and host many significant $\mathrm{U}, \mathrm{Sn}$, and Au deposits worldwide. Rare earth-critical syenitic fenites around alkaline intrusions share mineralogical and genetic traits with episyenites.
\end{abstract}

Keywords Episyenite $\cdot$ Metasomatism $\cdot$ Na-metasomatism $\cdot$ Uranium $\cdot$ Tin $\cdot$ Gold $\cdot$ Hydrothermal processes $\cdot$ Critical metals

\section{Introduction}

The term episyenite was coined by Lacroix [1] to describe, from the French Pyrenees, metasomatic (epigenetic) syenites whose magmatic protolith could not be identified with confidence. While the definition by Lacroix does not regard protolith mineralogy, the term is invariably used to describe sub-solidus, quartz-depleted alkali-feldsparrich rocks. Hydrothermal U-mineralization in quartzdepleted cavities amplified the interest in episyenite formation in the latter half of the twentieth century and their origin and mineralogy was elaborately studied in the

E. Suikkanen

einari.suikkanen@helsinki.fi

1 Department of Geosciences and Geography, University of Helsinki, Helsinki, Finland
Variscan granite massifs in France and vicinity [2, 3]. Since then, knowledge about episyenite occurrences, their formation conditions, associated fluids, mineralogy, and ore-forming potential has significantly increased. For example, while $\mathrm{U}$ is by far most important commodity associated with episyenites ([3-5] and references therein), Sn$\mathrm{W}[6-9], \mathrm{Au}[10,11]$, and rare earth element [12] mineralization have also been documented. Hence, these rocks may be attractive targets of mineral exploration, with potential to cater to the needs of the modern industry. In addition, modern in situ dating methods provide further opportunities to date episyenitization and vug-filling stages, which then allow integration of hydrothermal events to regional geological evolution $[4,13]$. Recent developments have prompted us to write this review of episyenites, our goal being a fresh point of view on their characterization and mineral potential. We also explore the fundamental processes of episyenite formation. 


\section{Episyenite Occurrences on a Global Scale}

Episyenite is a relatively rare result of hydrothermal alteration of granitoids rocks and migmatites. Notable occurrences and characteristic features of episyenites are shown in Table 1. Their environments and processes of formation are varying, but most commonly they are associated with sub-vertical fault systems within the upper continental crust, formed in a late- to post-orogenic or anorogenic setting during exhumation of orogenic roots or continental rifting (e.g., [4, 23]). Especially voluminous data are available from the commonly Umineralized episyenite occurrences in the Variscan, I- and Stype granitoids and migmatites that were episyenitized during late-Variscan to post-Alpine time. These include the French Variscan granitoids in the Pyrenees [19], Massif Central [3, 30], and Armorican Massif [4]. Rare example of episyenites formed in Variscan granites in a collisional orogenic setting has been described from the Mont Blanc Massif [21]. Several occurrences are also found within the Variscan granites in Portugal [8, 22], Spain [10, 18, 32], the Bohemian Massif of Czech Republic [33], and Germany [24], as well as the Tauern Tectonic Window in Austria [23, 34]. Episyenites of Proterozoic age, often associated with post-orogenic or Atype granite magmatism, are found worldwide: Sweden [14, 16], Finland [17], Brazil [7, 27], and Ukraine [5]. Younger post-orogenic or anorogenic occurrences include $\mathrm{Sn}-\mathrm{W}$ mineralized episyenites in the late-Jurassic Xihuashan granite in the Nanling metallogenic range, South China, [9] and in the late-Paleozoic Emuford and Go Sam granites in Queensland, Australia [6, 35]. Episyenites significantly enriched in the heavy rare earth elements have been described from New Mexico, USA, and may be connected to early Paleozoic carbonatite and alkaline magmatism [12]. In addition, many albitite/microclinite occurrences in the Jurassic-Cretaceous Nigerian ring complexes can probably be classified as episyenites [36]. Recently, episyenite has also been described from central Japan, hosted by the Cretaceous Toki granite [25], being the first episyenite discovered in an island arc setting.

\section{Naming Conventions and Classification}

Episyenites are a heterogeneous group of rocks and, accordingly, their classification is not simple. Most episyenite literature focus on the easily identified, vuggy low-temperature type, which is also the subject of Cathelineau's [2] classic review of episyenites from the French Massif Central. Episyenites, however, include both quartz-depleted, porous types (e.g., $[23,25])$, and variants in which porosity is lost to vug-infilling and/or deformation $[5,7,17,27]$. We use the term episyenite in the sense of "a sub-solidus, quartz-depleted rock", which is in accordance with episyenite literature $[2,3]$.
Quartz depletion implies nearly complete disappearance of primary quartz. As this type of alteration typically affects granitoids and is accompanied by alkali metasomatism, the resulting rocks tend to have mineralogical composition corresponding to an igneous syenite according to Streckeisen [20], i.e., $>65 \%$ albite $\left(\mathrm{An}_{<5}\right)$ and/or K-feldspar and $<5 \%$ quartz. The process of episyenite formation, or specifically quartz dissolution, is called "episyenitization." Some episyenites and rocks subjected to regional albitization may have an episyenitic facies comprising mainly albite, commonly referred to as albitite $[10,19,27]$. It should be noted, however, that albitite is used in reference to albite-rich metasomatic rocks in many different crustal environments, including orogenic gold deposits [37], and not all albitites are episyenites by our definition [38]. Some episyenites comprising mainly Kfeldspar have been referred to as microclinites [9] or potassic episyenites [7]. Overall, while descriptive terms (e.g., albitite) and prefixes (e.g., Kfs-episyenite) can be useful, their usage should be clearly defined in every contribution to avert ambiguity.

Alkali-metasomatic rocks in contact metasomatic (fenitic) aureoles around alkaline intrusions may also contain syenitic, quartz-depleted variants [39]. As fenites are a complex but widely studied and well-defined group of rocks [40], they are not included in our definition of episyenite. The existence of quartz-depleted fenites, however, further implies that wide range of geological conditions may lead to de-quartzification, and that the products sub-solidus syenitization processes are very variable. Within fenitic aureoles, large chemical gradients between alkaline magma bodies and granitic wall rock may lead to fluid-mediated up-temperature diffusion of $\mathrm{Si}$ [41], and quartz may also react with the metal-rich fluids to form large amounts of, e.g., aegirine-rich pyroxene. The relative importance of these processes sets syenitic fenites apart from most episyenites described in literature, in which dissolution of quartz and removal of $\mathrm{Si}$ in advecting fluids (i.e. leaching of quartz) dominate. In addition, pore fluid mediated Si-diffusion may result in quartz-free selvages around orogenic quartz veins during repeating crack-flowseal events associated with strain-, temperature-, or pressurerelated chemical gradients [15]; these are also not traditionally considered episyenites (but cf. [21]).

\section{Field Observations}

In the field, episyenites form lenticular or pod-, pipe-, and vein-like bodies that range from decameters to hundreds of meters in length and up to few tens of meters in width (e.g., $[17,22])$. They may be associated with faults $[23]$ and generally form elongated, discontinuous bodies parallel to the strike; in some cases, however, their connection to regional structures is not clear $[6,17,32]$. For various examples of 


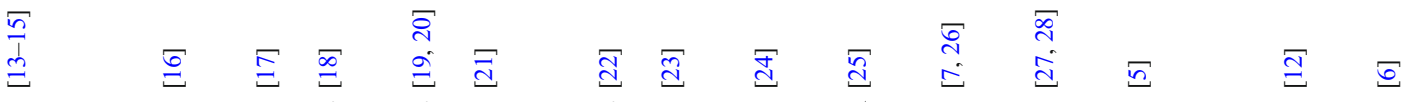

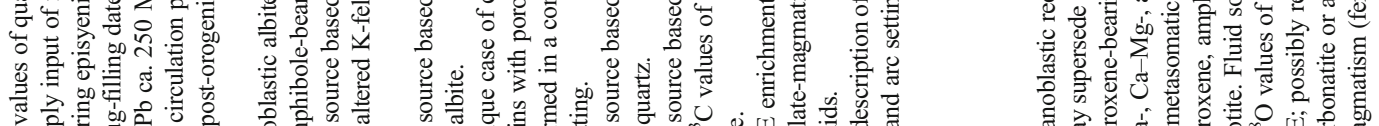

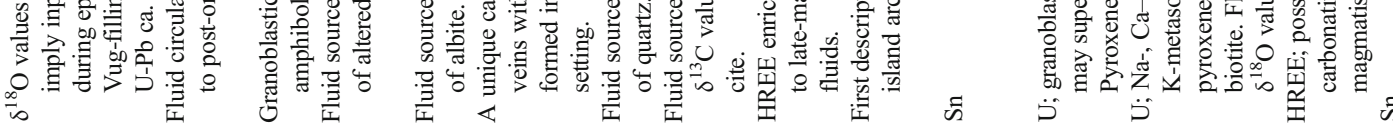

空

(1)

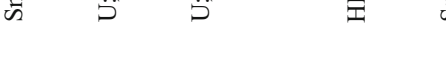

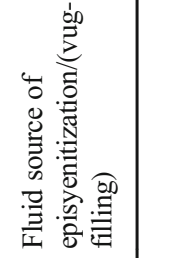

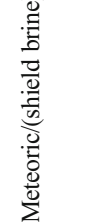

HH

11

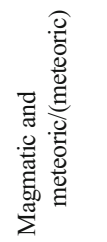

है

喜

पे ㅎำ

言:

离高部

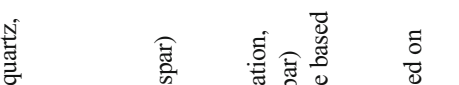

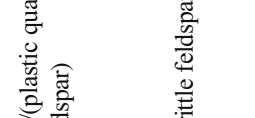

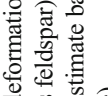

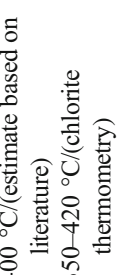

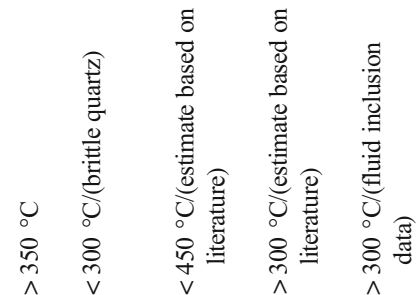

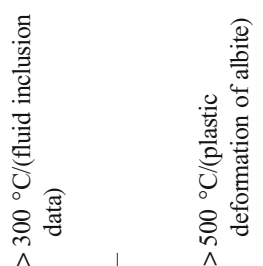

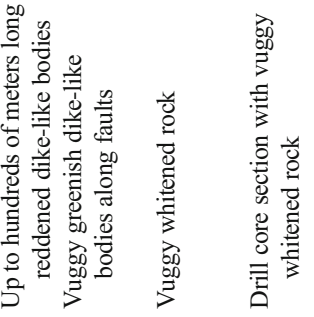

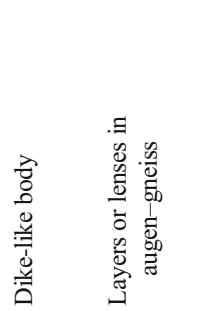

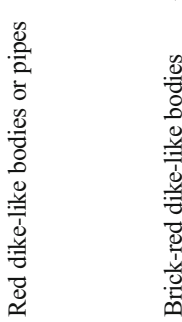

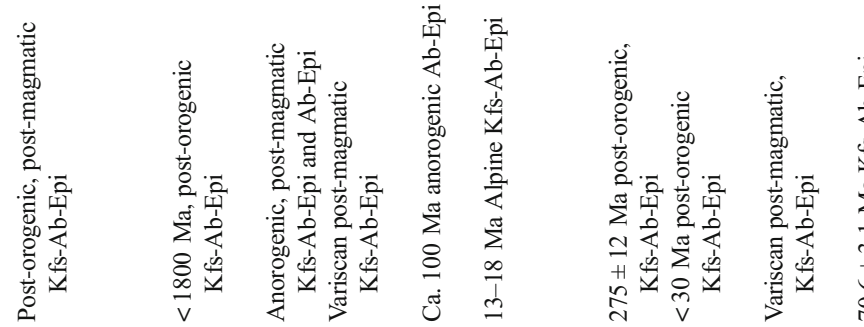

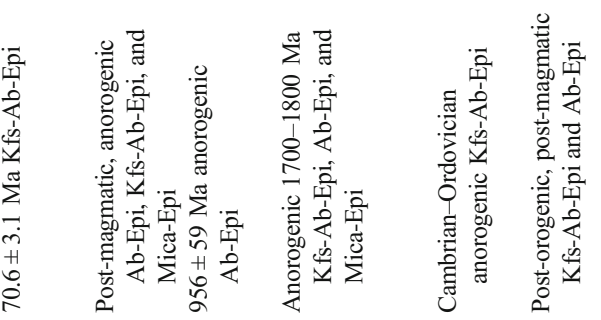

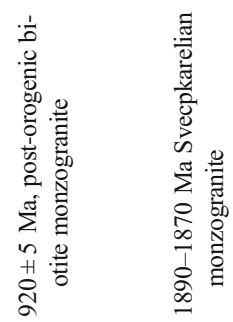

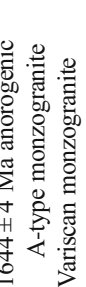

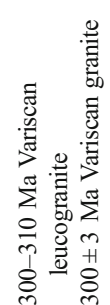

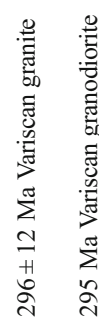

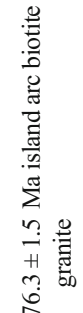

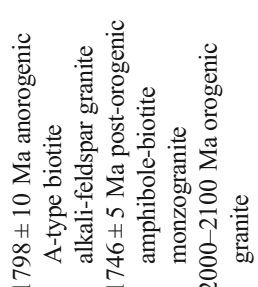

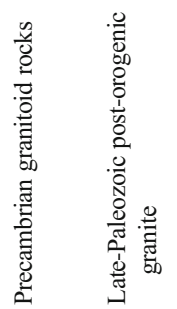

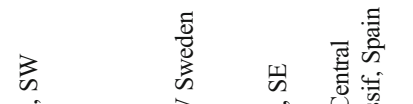

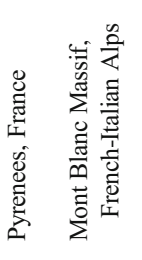

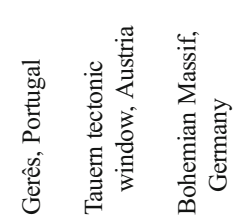

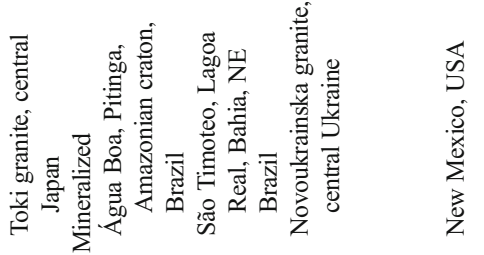


episyenite textures on outcrop and hand samples see, e.g., [16, $22,23]$ and [17]. On outcrop, episyenites are commonly distinguished either by their porosity [23] or by the conspicuous red or white color caused by alteration of K-feldspar or albitization [10, 22, 25] (Fig. 1). Some macrotextural features of the protolith, such as feldspar phenocryst shapes or relict gneissose lineation, are typically preserved during episyenitization [16, 42]. In some cases, some or all of these features are masked by deformation, vug-infilling, and/or weathering (Fig. 1). Contacts between protolith (usually granite) and quartz-free episyenite are sharp or have narrow transitional zones (e.g., corroded quartz, albitization; [43]). A common feature of episyenite is the tendency of quartzdepleted areas to transcend pre-episyenitization lithological boundaries such as aplite veins [6, 11, 23, 42]. Extensive quartz veining is not characteristic, implying long-distance transport of $\mathrm{Si}$ along the episyenitized structures. Some episyenite bodies described, however, have quartz-enriched border zones [7, 44] or cross-cutting quartz veining [6]. In addition, bodies of porous episyenites with a central quartz vein have been described from the French Mont Blanc Massif [21].

\section{Mineralogical and Textural Characteristics}

Two major mineralogical changes, quartz dissolution and alkali metasomatism, apply to any episyenite. Dissolution of mafic minerals and crystallization of hydrothermal minerals in quartz-depleted cavities are also characteristic (e.g., figure 3 in Jaques et al. [22]; Fig. 1c, d). A typical episyenite comprises mainly albite, microcline, and chlorite, both as pseudomorphic replacements of primary magmatic minerals and as cavity infills. Secondary quartz is usually present in the cavities.

Varying host rock composition and one or more stages of alteration with varying temperature, fluid chemistry, and fluidrock ratio result in high variability in both the major and accessory minerals of episyenites $[45,46]$. Assessment of different stages of alteration (deuteric alteration and subsequent metasomatic sequence) and hydrothermal mineral growth is not trivial. Remnants of magmatic quartz are commonly separated from secondary vug-filling quartz by plastic deformation in the former and the undeformed nature of the latter, although this simplification may not always be appropriate. In addition, the timing of albitization in relation to quartz depletion has also been the subject of active discussion [6, 10, 24]. These problems are significant as episyenite genesis is inferred from the paragenesis present and the chemistry of secondary mineral phases as well as fluid inclusions (e.g., [10, 18]). Overall, the extent of metasomatic replacement in granitic rocks is ambiguous; albitization may be selective, affecting only the most reactive minerals (plagioclase $>\mathrm{K}$-feldspar) and the texture of albitized rocks may be difficult to 
distinguish from magmatic textures (see figure 7 in [16]). In situ chemical analyses of minerals and radiogenic isotope analyses may be useful in dealing with this issue. $\mathrm{Rb}-\mathrm{Sr}$ and $\mathrm{K}-\mathrm{Ar}$ dating have been used to date metasomatic processes using neoformed feldspar, mica, and amphibole [25, 47]. In addition, dating of hydrothermal apatite [4], uraninite [10], xenotime [13], zircon, titanite, and monazite [42] has been successfully used to date episyenitizing and mineralizing processes.

\subsection{Feldspars and Their Replacement}

Alkali feldspar is the most common mineral in episyenites and is usually found as end-member albite $\left(\mathrm{Ab}_{99}\right)$ or microcline $\left(\mathrm{Or}_{>90} \mathrm{Ab}_{<10}\right)$. Based on feldspars, episyenites can be roughly divided into albitites (e.g., >90\% modal albite), albite-Kfeldspar episyenites, or rare microclinites. Magmatic plagioclase alters initially to albite along twin boundaries and grain margins [23] and is commonly completely pseudomorphed by albite ( $\left.A b_{99}\right)$. Replacive albite after K-feldspar may form chessboard pattern [6]. Albite and microcline are also typical as early vug- filling phases, forming clear or fluid inclusion -rich epitactic overgrowths on earlier feldspars [16, 22] (Fig. 1c, d). Formation of hypersolvus alkali feldspar has been suggested in some episyenites of the Suomenniemi rapakivi granite complex, Southern Finland [17]. Initial albitization in episyenites can be overprinted by microclinization or micaceous alteration [7], as well as late argillic alteration [14, 30]. Brittle fracturing and, to lesser extent, plastic recrystallization of feldspars leading to grain size reduction are common in episyenites [17, 22] (Fig. 1d, e). Deformation, recrystallization, and extensive feldspar crystallization within cavities can lead to overprinting of the porous episyenite texture.

Recent advances in metamorphic petrology stress the importance of dissolution-reprecipitation mechanism in metasomatic processes [48]. At elevated temperatures, equilibration of alkali feldspar in the presence of an aqueous fluid is fast [49] and generation of transient porosity during dissolution and reprecipitation of feldspar increases rock permeability, which is important in regional metasomatism [50]. Dissolution-reprecipitation in feldspars commonly leads to formation of turbidity, which is caused by numerous fluid
Fig. 1 Examples of episyenites from the Suomenniemi rapakivi granite complex in the field and in thin section samples after Suikkanen and Rämö [17]. a Episyenite almost

indistinguishable from its host Atype granite because of preservation of overall macroscopic texture and efficient vug-infilling by albite and quartz. b Porphyritic Atype granite episyenitized. Deep red color is caused by hematite on grain boundaries. c

Photomicrograph of the episyenite in $\mathbf{a}$, where albite, rich in fluid inclusions, forms epitactic growths on Kfs, and quartz fills the central cavity. Crossed polarizers. d Photomicrograph of the episyenite in a with fragmented and pervasively turbid Kfs (brown) overgrown by albite. Needles of ferro-ferri hornblende have grown in cavities and fractures in Kfs. Planepolarized. e Photomicrograph of albite episyenite close to $\mathbf{b}$ with deformed albite crystal replaced by and surrounded with granoblastic albite. Crossed polarizers
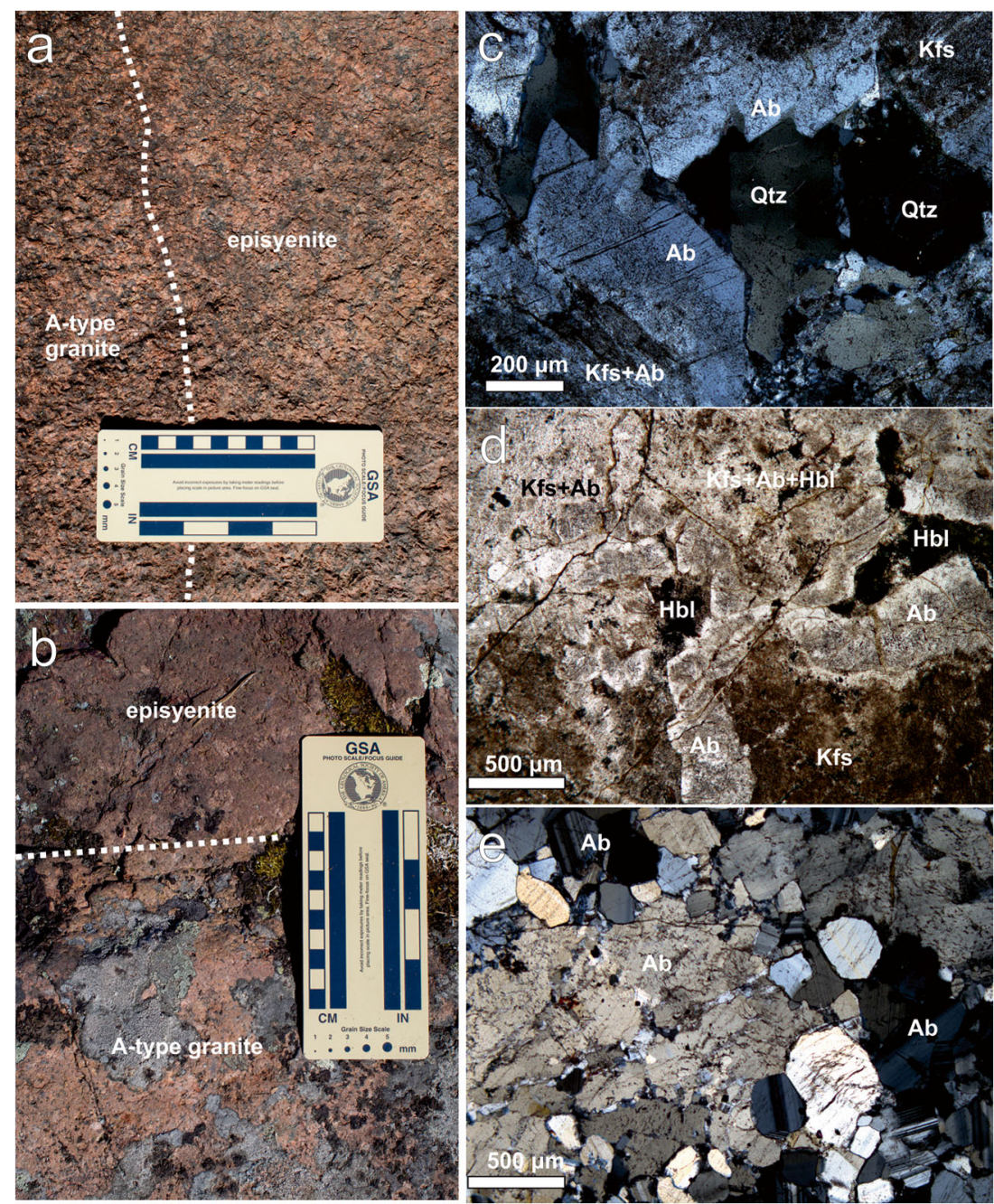
and solid inclusions [51, 52], recognized in many episyenites (e.g., [10, 17]; Fig. 1). According to Suikkanen and Rämö [17], the deep red color in some episyenites of southern Finland is caused by thin films of hematite on grain boundaries of granoblastic, recrystallized feldspar, as opposed to inclusions.

\subsection{Ferromagnesian Minerals}

Chlorite, commonly vermicular, is by far the most common $\mathrm{Fe}-\mathrm{Mg}$ mineral in episyenites, filling cavities, and fractures, and replacing magmatic phases (e.g., [2, 23]). Relicts of magmatic biotite or amphibole may be present, but complete disappearance of these minerals is also common. The mineralogy of episyenites that have suffered unusually high temperatures $\left(>450{ }^{\circ} \mathrm{C}\right)$ during or after episyenitization includes fenite- or skarn-type mafic silicates, either in cavities or replacing quartz. These may

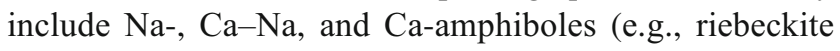
and actinolite; $[5,17])$ and hedenbergite-aegirine-augiteaegirine $[5,17,27,46]$, as well as hydrothermal biotite [5, 17]. These high-temperature metasomatic minerals may be overprinted by later chloritization $[5,46]$.

\subsection{Accessory Minerals}

Primary accessory minerals in episyenite protoliths-e.g., monazite, allanite, titanite, and zircon-may be lost to alteration; this is seen as notable LREE or HREE depletion in some albitites, as well as growth of secondary REE, Zr, U, and/or Ti-bearing minerals [5, 10, 18]. Fluorite is commonly present in cavities within F-rich granites [6,53]. Apatite, fluorite, titanite, chlorite, muscovite, xenotime, magnetite/hematite, and epidote form after primary ferromagnesian minerals and iron oxides either as pseudomorphic replacements [14] or in cavities. Carbonate minerals (ankerite, calcite), hematite, muscovite, and illite form late vug-filling assemblages. Ore minerals may be found in cavities or within metasomatic minerals; these may include Sn-oxide cassiterite, U-minerals uraninite, brannerite and coffinite, or sulfides such as arsenopyrite that may be associated with gold.

\section{Chemical Evolution and Mass Balance Analysis}

The chemical composition of episyenites varies considerably because of differences in protolith composition, element mobility during metasomatism, and authigenic mineral growth (e.g., $[10,44])$. The chemical evolution of an episyenite can be assessed by mass balance analysis $[54,55]$ that, in conjunction with mineralogical and textural data, delivers quantitative or semi-quantitative data on element mobility [5]. Because of the typical polymetasomatic nature of episyenites (e.g., [24]), applicability of mass balance analysis may be low [6] unless distinct metasomatic stages are recorded in the rocks examined [5]. In addition, quantitative mass transfer modeling is possible only if the change in the volume of the system or mass change of at least one element is known; these requirements are often unreasonable considering the complexity of episyenite systems. Thus, all mass transfer models concerning episyenites are practically semi-quantitative.

Semi-quantitative mass transfer models are commonly built by measuring porosity $[23,25]$ or otherwise estimating volume change, estimating immobile elements via isocon analysis, or assuming immobility of $\mathrm{Al}$ (e.g., [5]). It should be noted that whereas the solubility of $\mathrm{Al}$ in pure $\mathrm{H}_{2} \mathrm{O}$ is very low, Walther [31] showed that its solubility is significantly increased in a $0.5 \mathrm{~mol} /$ $\mathrm{kg} \mathrm{NaCl}$ solution (e.g., seawater) at $\mathrm{P}-\mathrm{T}$ conditions relevant to episyenite formation $(0.5-2 \mathrm{kbar}$ and 400 $600{ }^{\circ} \mathrm{C}$ ). Newton and Manning [26] suggested a significant increase in $\mathrm{Al}$ solubility in $\mathrm{Si}-\mathrm{Na}-\mathrm{H}_{2} \mathrm{O}$ fluids at $10 \mathrm{kbar}$ and $800{ }^{\circ} \mathrm{C}$. Significant input of $\mathrm{Al}$ via crustal fluids is thus possible, and likely required in albitization of mafic rocks [29]. Moreover, it is obvious that $\mathrm{Al}$ cannot be strictly immobile in metasomatic reactions involving aluminosilicates, although it could be immobile on the scale of a geochemical sample [56]. It is plausible that new vug-filling alkali feldspar is built solely from $\mathrm{Al}$ released by ferromagnesian phases and plagioclase during metasomatism. This debatable but practical simplification of element immobility has also been used with relatively immobile trace elements such as $\mathrm{Zr}$ or $\mathrm{Ti}$ [24].

The major geochemical changes in episyenitization are the result of removal of quartz and possible albitization or $\mathrm{K}$-feldspathization, i.e., addition of $\mathrm{Na}$ or $\mathrm{K}$ and removal of $\mathrm{Si}$, with most episyenites moving towards the composition of albite with increasing fluid-rock ratios. K-metasomatism is usually preceded by Na-metasomatism [5, 7]. Ca is usually removed during albitization of plagioclase, but may be added if late vug-filling phases include carbonates [23]. The feldspar replacement reactions are usually accompanied by coupled removal or addition of feldspar-bound trace elements $(\mathrm{Ba}, \mathrm{Rb}$, and $\mathrm{Sr})$. The behavior of $\mathrm{Al}$ during alkali-metasomatism is not clear, but it may be either added [23] or be practically immobile $[5,16]$. Increase in $\mathrm{Mg}$ is implied in many episyenites, which may suggest seawater component in the associated fluids [5]. Where the oxidation state of iron has been analyzed, oxidation of $\mathrm{FeO}$ to $\mathrm{Fe}_{2} \mathrm{O}_{3}$ is suggested $[14,17]$. REE or LREE depletion has been reported in some episyenites [10, 22, 57], whereas HREE enrichment is sometimes observed, this effect being usually rather weak [14, 22, 24, 57]. 


\section{Constraints on Episyenite Formation}

The relatively rare occurrence of episyenites suggests that conditions for their formation are not commonly encountered in the crust [10]. The following sections outline various processes and genetic constraints in episyenite formation, including shear zones and their connection to fluid and mass transport, Si solubility in crustal fluids, and the significance of magmatic processes.

\subsection{Fluid Sources}

Fluid inclusions have been widely used to study the source, composition, and temperature of episyenitizing fluids. Fluid immiscibility and fluid mixing as well as sequential alteration processes $[5,24]$ pose a major challenge. Several fluid inclusion populations are usually present and the relative timing of alteration and growth of minerals and entrapment of fluid inclusions must be well established to produce meaningful data. In addition, fluid inclusions can only provide indirect clues to the composition of episyenitizing fluids, as quartz dissolution is not necessarily connected to vug-infilling [6]. For example, dating of vug-filling minerals of episyenite in the Proterozoic Bohus granite, southwestern Sweden, suggests that their growth may have resulted from reactivation of permeable episyenite structures more than $100 \mathrm{Ma}$ after vug formation [13].

Fluid inclusion data are commonly used in conjunction with $\delta^{18} \mathrm{O}$ values of metasomatic and hydrothermal minerals (e.g., quartz and feldspar) and independent temperature estimates (mineral thermometry) to calculate fluid $\delta^{18} \mathrm{O}$ values in search of further evidence of fluid sources (e.g., [5]). Stable isotope data $\left(\delta^{18} \mathrm{O}\right.$ and $\left.\delta \mathrm{D}\right)$ have also been used on their own to estimate fluid sources (e.g., [18]). However, the reliability of stable isotope data must always be carefully considered, as $\delta^{18} \mathrm{O}$ of a crustal fluid may be buffered by country rocks, leading to loss of meteoric fluid isotope signature. Because of this, magmatic fluids may play a far lesser role in episyenitization than assumed. Keeping these problems in mind, fluid inclusion and stable isotope studies suggest that the fluids associated with episyenitization include meteoric $[19,23,58]$ and magmatic fluids $[6,18,30]$, mixtures of magmatic and meteoric fluids [22, 59], metamorphic fluids [45] as well as and basin formation waters [5]. Low to medium salinity $\left(<20 \mathrm{wt} \% \mathrm{NaCl}\right.$ eq.) $\mathrm{H}_{2} \mathrm{O}-\mathrm{Cl}$ fluids are typically inferred for the episyenitization stage, whereas late fluids related to vug-filling and ore deposition are dominantly meteoric low salinity $\left(\mathrm{CO}_{2}\right)-\mathrm{Cl}-\mathrm{H}_{2} \mathrm{O}$ fluids. Metamorphic and magmatic fluids may have respective roles in deposition of $\mathrm{Au}$ and $\mathrm{Sn}[10,59]$.

\subsection{Shear Zones}

Fractures and shear zones are important loci for fluid flow and metasomatism in the continental crust [60-62]. The style of deformation (brittle or plastic) in shear zones depends on temperature, pressure, strain rate, mineralogy, and the presence of a fluid. At low temperature and pressures and high strain rate, rocks deform by fracturing and frictional grain-boundary sliding, whereas at higher temperatures and in the presence of fluid, dislocation or diffusion creep [63] and dissolutionreprecipitation creep $[64,65]$ dominate.

Important transitions in the behavior of crustal rocks and shear zone permeability occur at the brittle-plastic transition of quartz (ca. $300{ }^{\circ} \mathrm{C}$ assuming a typical geothermal gradient of $25-30{ }^{\circ} \mathrm{C} / \mathrm{km}$ ) and feldspar (ca. $450{ }^{\circ} \mathrm{C}$ ). Essentially, pore fluids may exist in hydrostatic pressure $\left(\mathrm{P}_{\mathrm{H}}\right)$ in the brittle upper crust (e.g., $>300{ }^{\circ} \mathrm{C}$ in quartz-rich lithologies) where interconnected open porosity facilitates extensive fluid fluxes over long distances. In contrast, permeability of the middle crust $\left(300-450{ }^{\circ} \mathrm{C}\right)$ is decreased due to fast pore closure caused by the large effective pressure $\left(P_{\mathrm{L}}-P_{\mathrm{F}}\right)$ and crystalplastic behavior of quartz $[62,66,67]$. The permeability of these transitional systems is likely controlled by episodic fracturing [62] and porous episyenitized structures may not survive without collapsing [32]. Below the brittle-ductile transition (e.g., $>450{ }^{\circ} \mathrm{C}$ and $6 \mathrm{kbar}$ ), fluid transport in shear zones is hindered by plastic deformation of feldspar and may be completely controlled by creep-generated dilatancy $[60,68$, 69] and interface-coupled dissolution-reprecipitation [48, 50]. Even in ductile systems, however, fracturing may have preceded [70] or accompany ductile shearing $[60,71]$.

Because the temperatures of episyenite formation are often more than $350{ }^{\circ} \mathrm{C}$ and high porosity is retained, their formation requires crustal thermal anomalies that steepen the local geothermal gradient. Dissolution of quartz and transport of $\mathrm{Si}$ during fluid advection depends not only on crustal permeability but also on solubility of $\mathrm{Si}$ in crustal fluids.

\subsection{Si Solubility in Aqueous Fluids}

Pressure, temperature, and dissolved salts (notably $\mathrm{Na}$ and $\mathrm{K}$ ) affect the solubility of $\mathrm{Si}$ in $\mathrm{H}_{2} \mathrm{O}-\mathrm{Cl}$ fluids [72-74]. Solubility of $\mathrm{Si}$ in pure water is significant at elevated temperatures and pressures $\left(\sim 0.5-1 \mathrm{wt} \%\right.$ at $2-5 \mathrm{kbar}$ and $\left.500{ }^{\circ} \mathrm{C}\right)$ [72]. However, because crustal fluids tend to be Si-saturated, and low (commonly hydrostatic) pressure conditions are typically inferred, retrograde quartz dissolution is considered important $[2,10]$. The field of retrograde Si solubility (solubility increasing with decreasing temperature) occurs in pure water within the temperature range of $550-375^{\circ} \mathrm{C}$ at low $(<900$ bar) pressure [75] (Fig. 2a). Within the retrograde field, large downtemperature gradients cause a sharp increase in Si solubility, triggering quartz dissolution. For example, a drop in 
temperature from 425 to $375{ }^{\circ} \mathrm{C}$ at 300 bar results in a $0.8 \mathrm{wt}$ $\%$ increase in Si solubility in pure water, and ideally a rock with $30 \mathrm{wt} \%$ quartz could be fully episyenitized with a fluidrock ratio of 375 . Added salts move the retrograde Si solubility field to a higher temperature and diminishes its extent, so that reasonable retrograde effects are only seen in fluids with low salinity ( $<5 \mathrm{wt} \%$; [16], their figure 14; Fig. 2b). The temperature range of retrograde Si solubility has been established in many fluid inclusion studies by chlorite and feldspar thermometry and other temperature estimates for episyenitization (e.g., [10]); lower temperature estimates (< $310^{\circ} \mathrm{C}$ ) have also been published $[22,23]$. Figure 2 shows that heating of a meteoric fluid descending along a fault may lead to quartz dissolution in the temperature range of 200$375{ }^{\circ} \mathrm{C}$, the effect being similar to retrograde solubility increase. The potential for prograde quartz dissolution extends to deeper systems than retrograde quartz dissolution ( $>8 \mathrm{~km}$ ) and it is possible that both of these mechanisms operate independently in the deep parts of a hydrothermal system.

Si solubility may increase (salting-in) or decrease (saltingout) depending on the concentration of dissolved salts. This effect can be quite successfully modeled by considering their effect on the density of water, although Si-salt complexing may also play a role in increasing Si solubility [73, 74]. In $\mathrm{H}_{2} \mathrm{O}-\mathrm{NaCl}$ solutions, the salting-in effect of dissolved $\mathrm{NaCl}$ occurs with the molar fraction $X_{\mathrm{NaCl}}<0.2(<44 \mathrm{wt} \% \mathrm{NaCl})$ at low pressures and high temperatures, relevant to episyenitization [72]. K has a somewhat larger salting-in effect than $\mathrm{Na}$ [73] and cation exchange during albitization of Kfeldspar has been suggested to affect quartz dissolution in episyenitizing fluids [6]. This mechanism is, however, hardly significant, as the effect of K-for-Na exchange would probably translate to a maximum of $1 \mathrm{wt} \%$ increase in Si solubility at $500{ }^{\circ} \mathrm{C}$ and $2 \mathrm{kbar}$ [73]. Hence, for significant quartz dissolution to take place, a large volume of rock would have to be albitized and the Si-undersaturated fluid would have to be channeled along a conduit before it re-equilibrates with the rock. At lower pressures, the effect diminishes further, with only a $0.2 \mathrm{wt} \%$ increase in Si solubility in a $1.9 \mathrm{~mol} / \mathrm{kg} \mathrm{KCl}$ solution compared with a $1.9 \mathrm{~mol} / \mathrm{kg} \mathrm{NaCl}$ solution at $600 \mathrm{bar}$ (Fig. 2b). Moreover, albitization is far more common than episyenitization and is not usually accompanied by notable leaching of quartz $[19,79]$. In addition to Cl-salts, the role of fluoride in increasing Si solubility in late-magmatic fluids has also been speculated [6], but its effect in this regard is unclear.

If decreasing pressure (or increasing temperature) moves an $\mathrm{H}_{2} \mathrm{O}-\mathrm{Cl}$ fluid into the two-phase region, the fluid will separate into a relatively concentrated saline fluid or a brine and vapor or a dilute supercritical aqueous fluid [77]. When the boiling results from pressure drop, quartz will initially precipitate, but subsequent open system evolution of the liquid and vapor may lead to local leaching of quartz. For example, if the dilute fluid escapes from the more dense saline brine and evolves separately, its cooling could lead to retrograde quartz dissolution [71]. Thus, while the overall effect of increasing fluid salinity to $\mathrm{Si}$ solubility is small (Fig. 2), boiling must be considered as a possible mechanism to bring a fluid to Siundersaturation in (nearly) hydrostatically pressurized systems above epizonal intrusions. In addition, $\mathrm{CO}_{2}$ has a negative effect on Si solubility and hence boiling may increase solubility of $\mathrm{Si}$ in $\mathrm{H}_{2} \mathrm{O}-\mathrm{CO}_{2}$ fluids.

Overall, the effects of retrograde and prograde quartz dissolution and to a lesser extent boiling are important in episyenite formation, especially within shear zones close to the brittle-ductile transition above cooling intrusions, where high thermal gradients and necessary high fluid-rock ratios $\left(10^{2}-10^{3}\right)$ may be achieved [16]. Above the retrograde field, increasing temperature and pressure increases the Si solubility significantly, but the high pressure and temperature result in diminished crustal permeability and decline in fluid flux; thus, episyenitization depends mainly on the achieved degree of Siundersaturation in the fluid, rather than absolute Si solubility. In addition to leaching (Fig. 3a), some quartz may also be consumed in metasomatic reactions (Fig. 3b), such as albitization of plagioclase [16], dehydration of amphibole [27], or crystallization of pyroxene [17, 38, 39]. Increase in $\mathrm{P}_{\mathrm{F}}$ within an episyenite body sealed by mineral growth may also lead to additional quartz dissolution, whereas subsequent hydraulic fracturing leads to formation of quartz veins [16] (Fig. 3c).

In view of the generally porous texture of episyenites described in the literature, as well as the need for high fluid-rock ratios, it is reasonable to assume that most episyenites (especially larger veins) form at $<1.3 \mathrm{kbar}$ and at temperatures below $500{ }^{\circ} \mathrm{C}$ (Figs. 2 and 4).

\subsection{Role of Magmatism in Episyenitization}

Magmatism is an important driver of hydrothermal circulation in the upper crust, making significant heat and mass transfer possible [80, 81]. Hydrothermal convection cells around intrusions may be long-lived, depending on crustal permeability, and tend to be focused on the edges of intrusions [82]. Because of magmatic intrusions, geothermal gradients are locally exceptionally high and brittle-ductile transition zones form above magma chambers in the middle and upper crust [71]. These zones act as impermeable caps for high-T magmatic fluids and result in transient high $\mathrm{P}_{\mathrm{F}}$. Continuing exsolution of fluid or increase in strain rate may result in high- $T$ brittle failure, opening transient pathways for magmatic fluids. In granitic systems, the fluid is probably $\mathrm{Si}$-saturated and opening of fractures leads to decrease in fluid pressure and quartz precipitation [71]. If the decrease in pressure leads to boiling of the magmatic fluid, two immiscible phases form: a relatively dense brine that may act as a powerful 


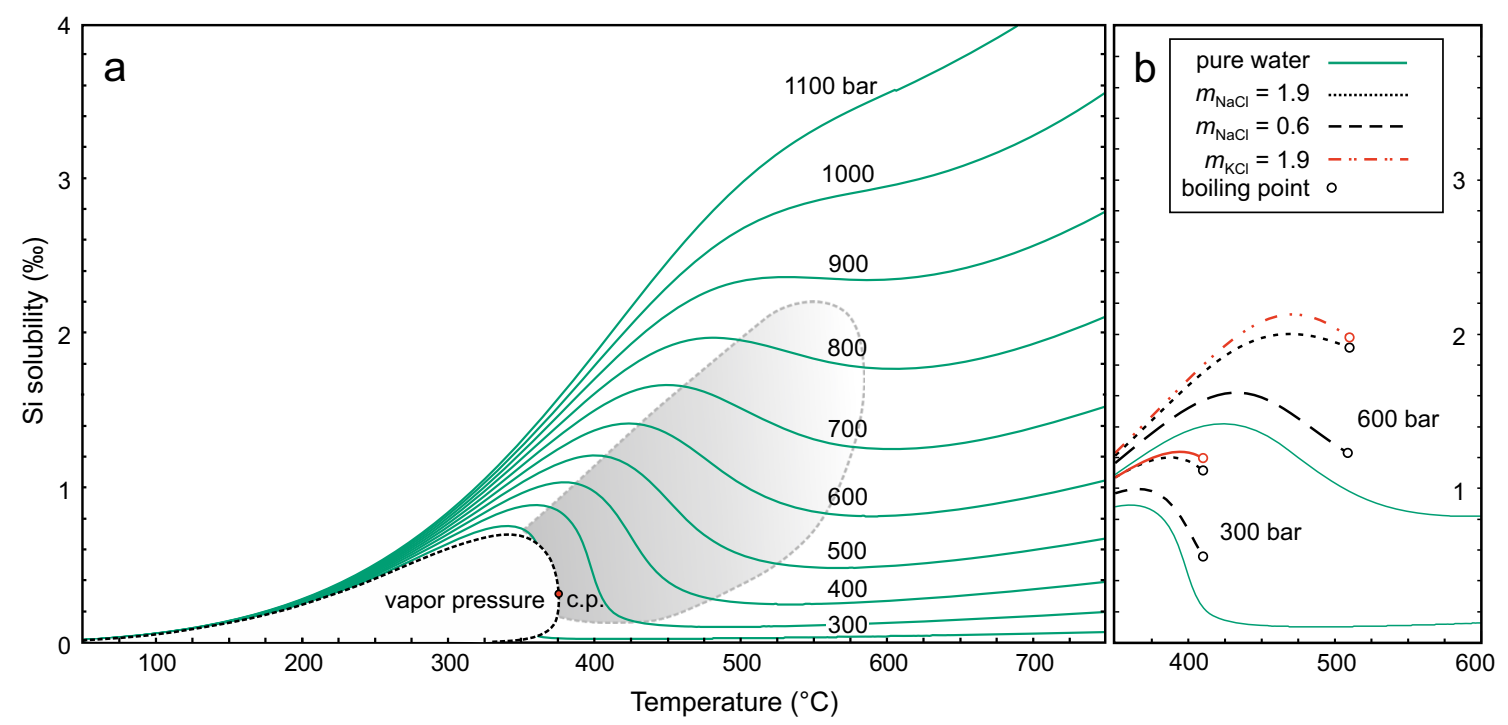

Fig. 2 a Solubility of $\mathrm{Si}$ in pure water, with the gray field implying retrograde increase of solubility (after Fournier [71] and Petersson et al. [16]). b Solubility of Si in $1.9 \mathrm{~mol} / \mathrm{kg} \mathrm{NaCl}(\sim 10 \mathrm{wt} \% \mathrm{NaCl}), 1.9 \mathrm{~mol} / \mathrm{kg}$ $\mathrm{KCl}$, and $0.6 \mathrm{~mol} / \mathrm{kg}(3.5 \mathrm{wt} \%) \mathrm{NaCl}$ fluids at 300 and 600 bar. Solubility curves were calculated according to the model of Akinfiev and Diamond
[73]. Molar volume data for pure water were calculated utilizing the $\mathrm{C}$ library "freesteam" (http://freesteam.sourceforge.net), an open-source implementation of the IAPWS-IF97 steam tables [76]. Boiling points for $\mathrm{NaCl}$ solutions are after Bischoff and Pitzer [77]; comparable boiling points are assumed for $\mathrm{KCl}$ solutions [78]. c.p., critical point of pure water metasomatizing agent, and a supercritical, low-salinity aqueous fluid that may act as a solvent if it enters temperature range of retrograde quartz solubility. Because of fast pore closure due to deformation, quartz precipitation and consumption of fluid in hydration reactions, it is unlikely that pervasive episyenite bodies form around these transient fractures. Outside the ductile cap of a cooling intrusion, thermal gradients are high and meteoric fluids may enter the hightemperature hydrothermal system.

Many episyenite studies conclude that episyenites found within a granite intrusion formed during the late-magmatic stage, as exsolving fluids escape through fractures within the crystalline roof of the magma chamber $[6,7,18,24,44]$ (Fig. 4). If the fluids are distinctly magmatic, no major regional structures (e.g., faults) need to be directly connected to the alteration zone, and local stress fields control the shape of the fracture networks and episyenite bodies [6, 8]. However, mixing of meteoric and magmatic fluids within the convection cells above the ductile cap of the intrusion leads to steep thermal gradients and contributes to high fluid-rock ratio required. Accordingly, for many episyenite occurrences in which magmatic fluids are suggested to have played a role, they supposedly mixed with meteoric solutions. Due to the problems with stable isotope analysis of rock-buffered fluid systems, however, separating magmatic and heated meteoric fluids may be difficult, and convincing evidence of an important magmatic fluid component may be lacking. For example, Recio et al. [18] suggested, based on the oxygen isotope composition of altered alkali feldspar and assuming alkali feldspar alteration and episyenitization to be concomitant, that late-magmatic fluids were responsible for episyenitization of granites at the Central Iberian Zone in Spain. In contrast, López-Moro et al. [10] noticed similar $\delta^{18} \mathrm{O}$-isotope characteristics in their samples from the Central Iberian Zone, but, based on uraninite dating and timing of albitization, concluded that the granite crystallization precedes episyenitization by $>10$ million years. Not only does this example illustrate the issue with tracing fluid sources using $\delta^{18} \mathrm{O}$ data, but also the common problem of connecting several types of alteration into a coherent model-can we know for certain that feldspar alteration preceded quartz dissolution?

Formation of episyenites may post-date the emplacement of their host granites by millions of years. Some researchers postulate that late intrusions could mainly provide the heat necessary for meteoric fluid circulation $[3,5,44]$. Others suggest that hydrothermal episodes forming episyenites were fueled by regional thermal anomalies within post-orogenic crust in extension, involving influx of meteoric [19, 22, 83] or metamorphic fluids [10]. The thermal energy for fluid circulation may have resulted from crustal magmatism in these cases as well. Because of the relatively low permeability of mid-crustal shear zones and importance of retrograde quartz dissolution, it seems unquestionable that magmatic heat generation is an important agent for episyenite formation (Fig. 4). Crustal thinning during post-orogenic extension [84] leads to magmatism and activation of fluid circulation within normal or strike-slip faults [85]. Extensive fault systems also accompany anorogenic continental rifting [61], which is 
a

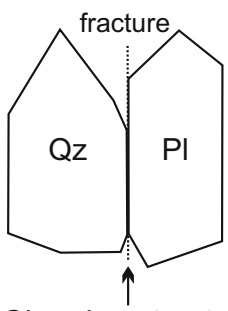

Si-undersaturated aqueous fluid
Leaching of quartz

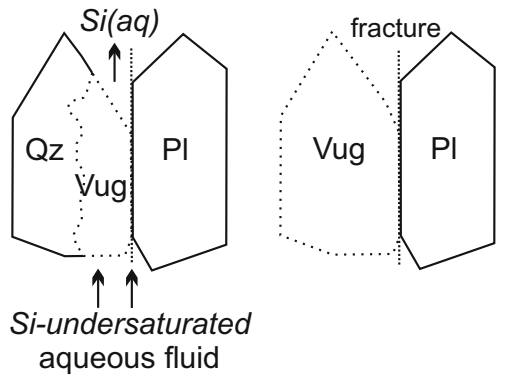

b Consumption of quartz in metasomatic reactions

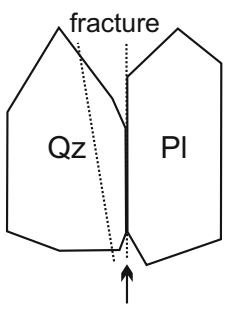

Fe-Na- $\mathrm{H}_{2} \mathrm{O}$ fluid

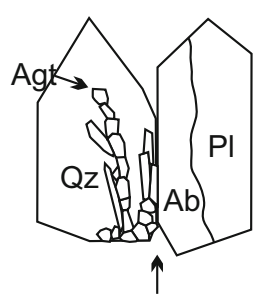

Fe-Na- $\mathrm{H}_{2} \mathrm{O}$ fluid

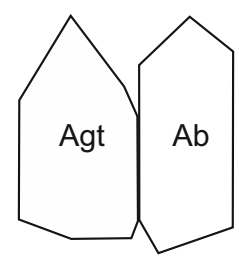

C Increase in fluid pressure in a closed episyenite body
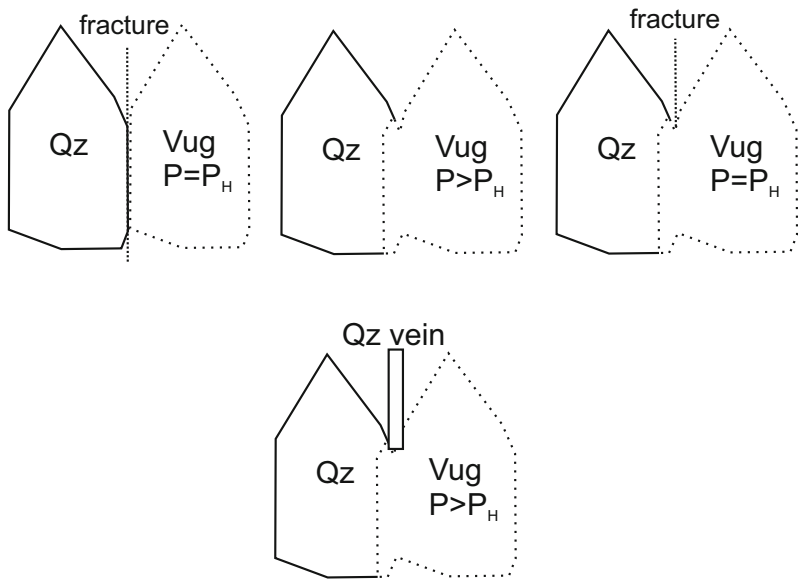

Fig. 3 Mechanisms resulting in quartz depletion in episyenites. a Quartz is leached as a Si-undersaturated fluid infiltrates an open fracture. High permeability and high time-integrated fluid flux associated with brittle shear zones and joints in the upper crust are required for significant leaching. b Quartz is consumed in metasomatic reactions, such as albitization $\left(2 \mathrm{Na}^{+}+4\right.$ quartz + anorthite $=2$ albite $\left.+\mathrm{Ca}^{2+}\right)$ and growth of pyroxene. $\mathbf{c}$ Increase in fluid pressure in an episyenite body sealed by mineral growth or compaction results in increase in Si solubility and additional quartz dissolution; subsequent pressure drop leads to quartz precipitation. In nature, albitization is likely to also accompany a. Ab, albite; Agt, aegirine-augite; Pl, plagioclase; Qz, quartz

accompanied by A-type and alkaline magmatism (Fig. 4). Shear heating and radiogenic heat production $[4,28]$ can also sustain hydrothermal circulation and impact regional metamorphism and anatexis of the lower crust. The heating of upper crustal fluids to temperatures of the Si retrograde field is probably not plausible with these mechanisms [28].

\subsection{Ductile Deformation of Feldspar in Episyenites}

Some episyenites have experienced ductile deformation of feldspar either during or after quartz dissolution and alkalimetasomatism [5, 17, 18, 27, 34] (Fig. 1b, e). As it may be difficult to produce the typical vein- or pod-like geometry of an episyenite in a setting with the porosity not staying open for prolonged periods of time, as infiltration of meteoric water to such system is hindered [66], timeintegrated fluid-rock ratios are low and significant chemical gradients between fluid and rock are untenable. It is likely that were quartz-depleted formed in such a setting, they would be associated with segregation quartz veins, or experienced extensive quartz replacement (e.g., [38]), which may be assessed by mass balance analysis and mineralogical observations.

Due to the difficulty of leaching of quartz in a ductile environment, brittle-to-ductile evolution may be envisioned for plastically deformed episyenites that lack evidence of significant quartz veining or quartz replacement. For example, porosity generated by quartz leaching may collapse due to increase in temperature or strain after episyenitization, which could be caused by intermittent magmatic events. Whereas limited brittle deformation of the typical, porous feldspathic framework is commonly observed, pervasive cataclastic or extensive ductile deformation is rare. It is possible that many deformed episyenites have not been recognized as episyenites at all, because evaluating early evolution (e.g., if quartz dissolution took place, and at what conditions) of deformed, weakly porous episyenites is challenging [17]. If the mineralogy and texture of an episyenite is overprinted by later sub-solidus processes, physical constraints of episyenitization (as discussed above) can be used as a guideline in estimation of $\mathrm{P}-\mathrm{T}$ conditions or fluid regimes during quartz depletion.

Examples of episyenites with difficult-to-constrain early histories include the episyenites from the Variscan granites in Sierra del Guadarrama, Spain [32, 46]; these episyenites show pervasive cataclastic fabric and their feldspars commonly display core-and-mantle structures. They were suggested to have formed at a depth of $>6.5 \mathrm{~km}$ at $350{ }^{\circ} \mathrm{C}$ (biotite-type) to $650{ }^{\circ} \mathrm{C}$ (clinopyroxene-type); initial hydrostatic fluid pressure during quartz dissolution increased close to $P_{\mathrm{L}}$ during cataclastic deformation. The reason for such high temperature alteration at Sierra del Guadarrama is unclear. Granoblastic recrystallization of albite has been described from aegirine-augite-bearing episyenites hosted by the epizonal Suomenniemi rapakivi granite complex, SE Finland [17]. In addition, some episyenite variants at Suomenniemi have hypersolvus feldspar, implying hightemperature conditions $\left(>650{ }^{\circ} \mathrm{C}\right)$ during or after episyenitization. A similar example of pyroxene-bearing 
uplift and exhumation

extension and rifting

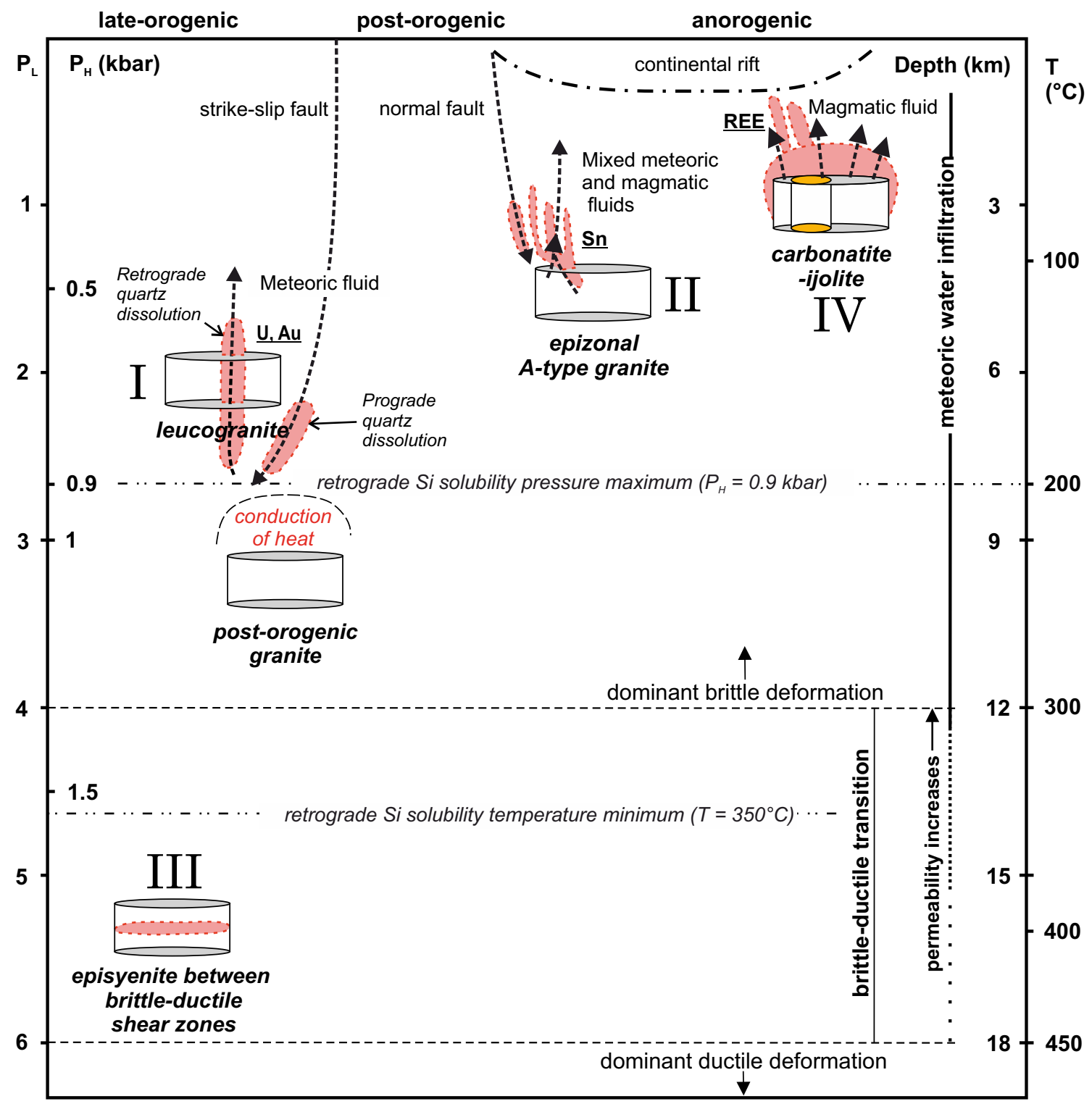

Fig. 4 Schematic illustration of common crustal environments with potential for episyenite formation (solid pink segments). Formation of syenitic fenite is shown for comparison. Background geothermal gradient is $25^{\circ} \mathrm{C} / \mathrm{km}$ and pressures $P_{\mathrm{H}}$ and $P_{\mathrm{L}}$ are calculated assuming densities of $1 \mathrm{~g} / \mathrm{cm}^{3}$ and $3 \mathrm{~g} / \mathrm{cm}^{3}$ for fluid and rock, respectively. Fluids are localized along brittle shear zones above intrusions in the upper crust. Local high geothermal gradients (at locations I, II, and IV) in the upper crust allow for retrograde (down-temperature) quartz dissolution and significantly enhance prograde quartz dissolution. I: U-enriched orogenic leucogranites and migmatites episyenitized because of deep crustal

episyenites with a high $\mathrm{P}-\mathrm{T}$ history has been described from the Central Ukrainian uranium province [5]. Within the episyenites of the Ukrainian province, hightemperature $\left(>500{ }^{\circ} \mathrm{C}\right)$ episyenitization and $\mathrm{Na}$ metasomatism are implied by plastic deformation of albite (notably, bent twin lamellae). At the Lagoa Real uranium province, south-central Bahia, Brazil [27, 86], Na- infiltration and magmatic heating of meteoric solutions. II: Episyenites and associated Sn-mineralization forming in epizonal post-orogenic or Atype granites by mixing of late-magmatic and meteoric fluids above the ductile cap of the intrusion. III: Episyenites and associated quartz veins form in response to vertical lengthening in an orogenic setting. III is analogous to quartz vein-selvage systems forming in regional metamorphism. IV: Syenitic fenites form around alkaline magmas as the result of expulsion of hypersaline fluids from the intrusion, with potential for rare earth element mineralization

metasomatism and uranium mineralization may have preceded greenschist-amphibolite facies regional metamorphism, which resulted in granoblastic recrystallization of albite. Melcher et al. [34] described alkali-feldspar-rich bodies within the Variscan granitic gneisses in the western Tauern Window, Austria. These rocks are suggested to be pre-Alpine episyenites that were deformed during the Alpine orogeny. 


\subsection{Continental Collision and Episyenites}

Episyenites from the Mont Blanc Massif (French-Italian Alps) formed between synkinematic, greenschist-facies, cataclastic to ductile shear zones that record peak metamorphic conditions at $\sim 450^{\circ} \mathrm{C}$ and $4-6 \mathrm{kbar}$ [21]. These are a rare example of episyenite formation in a compressional tectonic setting (Fig. 4). They formed along horizontal fractures associated with vertical stretching at temperatures between 350 and $420{ }^{\circ} \mathrm{C}$. The episyenite system comprises a central quartz vein with porous, quartz- and biotite-depleted, alkalimetasomatized selvages (episyenites) whose vugs are lined with albite, adularia, quartz, and chlorite. Rossi et al. [21] suggested that the episyenites formed essentially in a closed system with insignificant mass transfer from the shear zones to the episyenite system and vice versa. The loss in quartz from the selvages accounts for quartz in the central vein, which implies that the episyenites formed between permeability caps (ductile shear zones) preventing efficient Si transfer out of the fracture. Limited fluid flow in these horizontal fracture systems [62] is a probable reason why episyenites are more likely found associated with sub-vertical strike-slip fault systems in extensional settings. In this case, the importance of diffusive instead of advective mass transfer is probably relatively high, compared with more typical episyenites in extensional settings. In this sense, they resemble greenschist-amphibolite facies quartz vein systems formed by local quartz segregation $[15,87]$, while lacking significant brittle-ductile deformation of the selvages.

\section{Mineral Potential}

Episyenites have often undergone several hydrothermal episodes, some of which may have led to ore mineralization. Significant commodities in episyenites include U, Sn-W, and $\mathrm{Au}$. Some potential exists for the rare earth elements as well but rare earth element mineralization in episyenites seems to be rare and no deposits have thus far been exploited. In addition, some albitite occurrences are mined for feldspar [88]. Usually, the mineralization is independent of quartz dissolution, and the resultant porous episyenite body acts solely as a sink for metals. The mineralization potential for $\mathrm{U}$ and $\mathrm{Au}$ in episyenites is highly dependent on the mineralogy and structure of the host rock and/or surrounding lithologic units and is distinctly post-magmatic. $\mathrm{Sn}-\mathrm{W}$ mineralization may be also connected to late-magmatic fluids in tin-enriched granites. Barren and mineralized episyenites can be found as part of the same episyenite structure [30], as some episyenitized rocks remain closed for subsequent fluid events. In addition, Patrier et al. [30] noted a direct relationship with strength of late illitization and U-mineralization; recognition of such proxies is vital for exploration.

\subsection{Uranium}

Uranium is the most important commodity related to episyenites. Episyenite-related U-deposits are especially common in the Variscan granites of Europe, with extensive and often economically significant occurrences in France [3, 4, 30] and the Czech Republic [33]. The episyenite deposits of the central Ukrainian uranium province [5] and the Lagoa Real uranium province in Bahia, Brazil [27, 86], are prime examples of Proterozoic U-mineralization.

It is commonly assumed that $\mathrm{U}$ is mobile primarily in oxidized fluids (as uranyl complexes), and deposition happens by reduction of $\mathrm{U}^{6+}$ to $\mathrm{U}^{4+}$ due to fluid mixing or interaction with reducing, e.g., sulfide-rich, rocks [45, 89]. Recent results by Timofeev et al. [90], however, suggest that $\mathrm{U}^{4+}$ is soluble at $>150^{\circ} \mathrm{C}$ in acidic $\mathrm{Cl}$-rich fluids, in which reduction leads only to change in speciation of $\mathrm{U}$ (from $\mathrm{UO}_{2} \mathrm{Cl}_{2}$ to $\mathrm{UCl}_{4}$ ). Their data show that precipitation of U-minerals from Cl-rich fluid may occur due to rise in $\mathrm{pH}$ (e.g., due to fluid-rock interaction), or cooling of reduced U-rich fluid.

Uranium in episyenites is sourced from U-rich metamorphic rocks or fertile leucogranites or felsic volcanic rocks. In general, granite fertility implies whole-rock U-content of > $10 \mathrm{ppm}$ and presence of $\mathrm{U}$ as leachable uranium oxide $[3,91]$. $\mathrm{U}$ is mobilized by circulation of fluids through faults, fractures, and other interconnected porosity within the fertile sources, followed by deposition of U-minerals within episyenitized channels. Leaching of U-bearing accessory (monazite, zircon, allanite) or major minerals (e.g., muscovite) during episyenitization may also provide some $U$ [45, 89]. Formation of significant U-mineralization is generally thought to supersede episyenitization (as in Fig. 5a, b), but the fluid carrying the $\mathrm{U}$ does not necessarily need to be distinct from the episyenitizing fluid.

\subsection{Tin}

Notable cassiterite deposits in episyenites are found in the Emuford granite in Herberton tin field, northern Queensland, Australia [6, 35], and the Água Boa granite in Pitinga tin province in northern Brazil [7]. These Sn-mineralized episyenites are related to reduced F-rich anorogenic or postorogenic granites that also show primary magmatic tin enrichment and greisen or vein-type mineralization. Episyenitization and albitization in these systems were suggested to be a response to the escape of magmatic Sn-bearing fluids from cooling plutons in the late-magmatic stage; the F-rich fluids present may have been important in increasing the Si solubility. After albitization and quartz dissolution, the cooling fluids became saturated with respect to quartz and cassiterite, leading to vug-infilling. Despite the high grade of the Sn-ore (up to $1.7 \mathrm{wt} \%$ at Pitinga) in these deposits, their economic potential is depressed by their low volume. Some episyenite-hosted tin 
Fig. 5 a Generalized episyenite formation sequence in fluid circulation cells above cooling upper crustal intrusions (I and II in Fig. 4). b, c Simplified examples of isovolumetric episyenitization during the sequence shown in a. Relative timing of major albitization phase and quartz dissolution (step 2) is usually unclear. Common features not shown are fracturing and phyllic alteration of feldspar and formation of mineral inclusions during feldspar replacement. b Leaching of quartz and biotite by a low-salinity fluid leaves a vuggy $\mathrm{K}$-feldspar rich episyenite that is later impregnated by a second, Umineralizing fluid. Lack of step 4 may result in a barren episyenite (e.g., [14]), unless mineralization has been coeval with episyenitization (cf. [45]). c Formation of albite-rich, Snmineralized episyenite associated with F-rich A-type granite after Charoy and Pollard [6] and Costi et al. [7]. In the case of c, the fluid has been relatively Na-rich, resulting in extensive albitization of K-feldspar. Ab, albite; Bt, biotite; Cc, calcite; Fl, fluorite; Hm, hematite; Ilt, illite; Kfs, Kfeldspar; Ms, muscovite; Pl, plagioclase; Tit, titanite; U-ox, uraninite

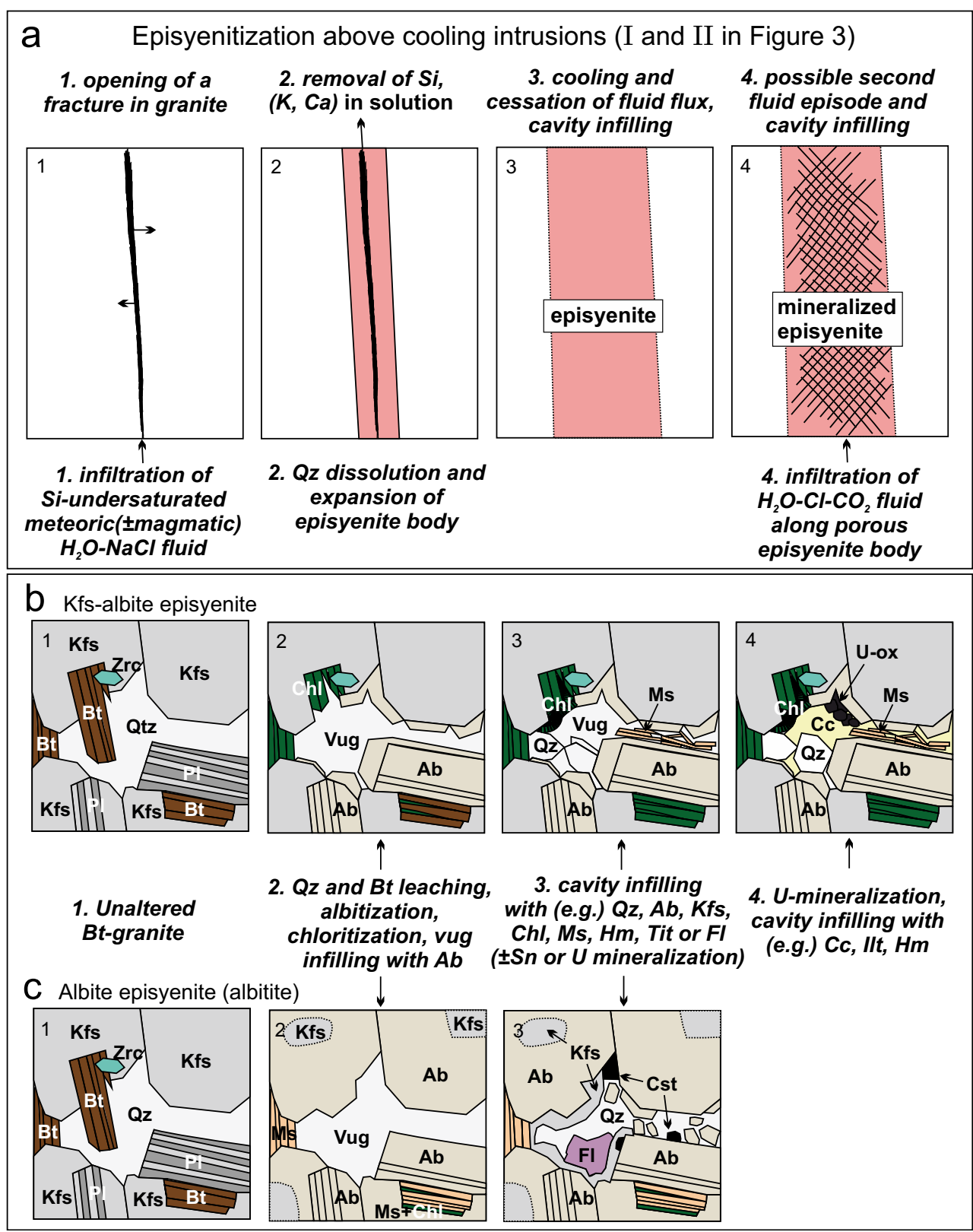

deposits have been exploited at Emuford. In contrast to these examples from Australia and Brazil, the emplacement of quartz-muscovite-wolframite veins in the Variscan Gerês granite, Portugal, was preceded by late-magmatic episyenitization, which only offered structural control for the post-magmatic mineralization [8].

\subsection{Gold}

Gold deposition in quartz-depleted vugs in episyenites has been documented for at least two localities, in the Basinand-Range province, southeastern Arizona [11] and in the Ricobayo granite, Central Iberian Massif, Spain [10]. In the Gold Basin ore district in Arizona, the gold- mineralized quartz-depleted may be the deeper equivalents of the more common gold-quartz vein systems in the area. Deposits in episyenites are associated with sulfides (pyrite, arsenopyrite) that may act as gold traps for circulating gold-bearing fluids, while sulfides are rare in most episyenites [10]. Related fluids may also have an ore-geologically important metamorphic association, which is seemingly rare in vuggy episyenites. Metamorphic fluids may also be important for the formation of orogenic gold deposits; while these deposits do not include episyenites in the traditional sense, albitite with economically important gold dissemination is sometimes present [37, 92]. For example, quartz vein -hosted gold deposits and associated albite-carbonate-quartz veins 
with quartz-depleted albititic selvages have been described from Burkina Faso, West Africa [92].

\subsection{Rare Earth Elements}

While alkali-metasomatism has played a role in the formation of some of the premier rare earth element deposits of the world, the rare earth element mineralization potential of episyenites is quite unexplored. Although REE-bearing accessory minerals such as monazite or zircon can be destroyed in metasomatic processes, the volume of episyenitized rocks is usually small, and concentration of the REE in economic quantities in normal granites seems uncertain. Some REE-enriched episyenites, possibly related to alkaline or carbonatite magmatism, are found in New Mexico [12]. These rocks may contain more than 1300 ppm REE, with especially significant enrichment of the HREE. This implies that in the case of a suitable high-REE (e.g., carbonatitic), fluid source REE mineralization is possible but may be restricted to fenites (see also [40]).

\section{Episyenite Formation Sequence}

Based on the considerations above, a general process for the most common cases episyenite formation in the upper crust can be outlined (I and II in Fig. 4):

1. In brittle bedrock undergoing dilation, fracture opens and is invaded by fluid. Decrease in fluid pressure may lead to quartz precipitation (Fig. 2).

2. Episyenite body expands due to leaching of quartz (Fig. 3a). Typically, a sharp down-temperature gradient in the field of retrograde Si solubility (e.g. $425-550{ }^{\circ} \mathrm{C}$ at 600 bar) or increase in temperature and pressure in the prograde region is required to bring fluid to $\mathrm{Si}$ undersaturation (Fig. 2). Some quartz may also be consumed in metasomatic reactions (Fig. 3b).
3. Albitization of plagioclase releases Al and leads to crystallization of alkali feldspar in quartz-depleted cavities (Fig. 5b).

4. Mafic minerals are affected in varying ways: Biotite and amphibole are commonly leached or chloritized. Chlorite as replacement and a vug-filling mineral is the most common $\mathrm{Fe}-\mathrm{Mg}$ mineral produced at this stage (Fig. 5b).

5. A decrease in fluid velocity (decrease in fluid flux and/or wall-rock permeability), cooling, or change in fluid composition causes the cessation of quartz dissolution as Si-saturation is reached. Quartz and other minerals (possibly including cassiterite or other ore) are precipitated during cooling (Fig. 5b, c), and Kfeldspar may replace albite.

6. Increase in $\mathrm{P}_{\mathrm{F}}$ in episyenitized fluid pockets sealed by mineral growth or compaction may locally lead to Siundersaturation (Fig. 2) and continued leaching of quartz, whereas subsequent pressure drop leads to quartz precipitation [16] (Fig. 3c). Thus, hydraulic fracturing of sealed episyenite bodies and their wall rock leads to formation of quartz veins (e.g., [6]).

7. If episyenitization takes place in high temperature or pressure (e.g., $P_{\mathrm{L}}>3 \mathrm{kbar}, T>500{ }^{\circ} \mathrm{C}$ ) or if the temperature and strain increase after episyenitization, the porosity generated by fracturing and quartz dissolution may collapse or become masked by plastic deformation of feldspar (e.g., Fig. 1e).

8. Authigenic minerals (most notably quartz, feldspar, calcite, chlorite, muscovite, illite) grow in pore space created by quartz dissolution and may fill it completely (Fig. 5b). This process may be temporally disconnected from the episyenitization itself and result from a distinct fluid infiltration episode (Fig. 5a). Ore mineralization (U, Au) may form during this phase.

This sequence does not take into account the rare case of episyenitization along horizontal fractures at mid-crustal
Fig. 6 Schematic representation of episyenitization by quartz vein segregation in compressional setting after Rossi et al. [21] (III in Fig. 4). The chemical gradient required for Si-diffusion is caused by fluctuation in fluid pressure during vein formation. Abbreviations as in Fig. 5

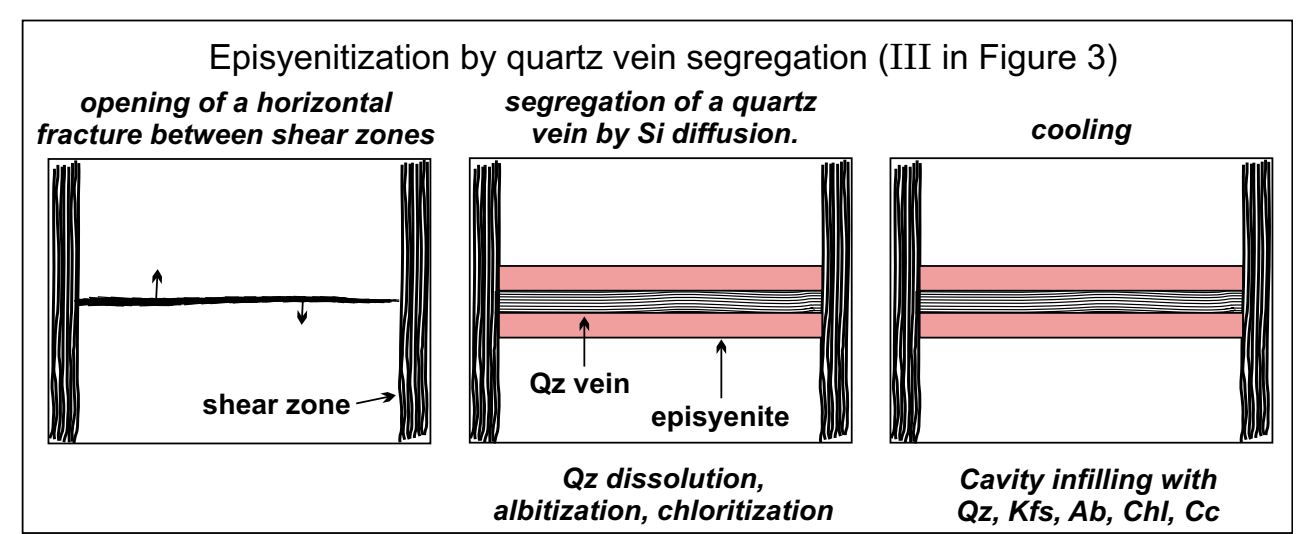


depth, as discussed by Rossi et al. [21], in which leaching or replacement is of small importance compared with diffusive Si-transport (Fig. 6).

\section{Conclusions}

Episyenites are quartz-depleted and commonly alkalimetasomatized rocks that typically comprise albite and/or microcline, chlorite, and muscovite in addition to varying vug-filling assemblages. In the field, they are found reddened or bleached veins, pods, or lenses that commonly have a vuggy and fractured texture resulting from quartz dissolution and limited brittle deformation. Visible porosity may be absent depending on the effectiveness of compaction, recrystallization, and vug-filling.

Episyenites typically form in response to interaction of a quartzbearing rock with a low to medium salinity Si-undersaturated $\mathrm{H}_{2} \mathrm{O}-\mathrm{Cl}$ fluid. Si-undersaturation is achieved in pertinent crustal fluids by either cooling of the fluid within the field of retrograde $\mathrm{Si}$ solubility, or heating within the field of prograde Si solubility. Infiltration of meteoric water into hydrostatically pressurized hydrothermal systems above cooling intrusions is the most favorable process for episyenitization, catering to the necessary steep thermal gradients and high fluid-rock ratios $\left(10^{2}-10^{3}\right)$. At least some quartz may also be consumed in metasomatic replacement reactions, including albitization and fenitization-style pyroxene growth. Sealing and fracturing of episyenite bodies result in fluctuation of fluid pressure, inducing additional quartz dissolution and quartz vein formation. Rare examples of episyenites from a compressional tectonic setting may have formed by quartz vein segregation.

In addition to quartz dissolution and alkali metasomatism, episyenites may record complex histories of alteration and hydrothermal mineral growth. Vuggy episyenites are important in ore genesis (particularly in mineralization of $\mathrm{U}$, but also of $\mathrm{Sn}-\mathrm{W}$ or $\mathrm{Au}$ ) as they act as metal sinks for crustal fluid transport because of their high (e.g., $>30 \%$ ) initial porosity and pore interconnectivity. Disseminated Sn mineralization may form during late-magmatic episyenitization above and within the roof zones of Sn- and F-rich A-type granite intrusions.

Acknowledgments Open access funding provided by the University of Helsinki. Reviews by Prof. Isabel Barton (University of Arizona) and an anonymous reviewer are gratefully acknowledged. This contribution was compiled in the framework of the University of Helsinki and Geological Survey of Finland collaboration project "Critical mineral potential and origin of rapakivi granite-related peraluminous and peralkaline felsic magmatism in southeastern Finland" (2015-2018), funded by the K.H. Renlund Foundation (a grant to O.T.R.).

\section{Compliance with Ethical Standards}

Conflict of Interest The authors declare that they have no conflict of interest.
Open Access This article is distributed under the terms of the Creative Commons Attribution 4.0 International License (http:// creativecommons.org/licenses/by/4.0/), which permits unrestricted use, distribution, and reproduction in any medium, provided you give appropriate credit to the original author(s) and the source, provide a link to the Creative Commons license, and indicate if changes were made.

\section{References}

1. Lacroix A (1920) Les roches éruptives du Crétacé pyrénéen et la nomenclature des roches éruptives modifiées. CR Acad Sci 170: 685-690

2. Cathelineau M (1986) The hydrothermal alkali metasomatism effects on granitic rocks: quartz dissolution and related subsolidus changes. J Petrol 27(4):945-965. https://doi.org/10.1093/ petrology/27.4.945

3. Leroy J (1978) The Margnac and Fanay uranium deposits of the La Crouzille District (western Massif Central, France); geologic and fluid inclusion studies. Econ Geol 73(8):1611-1634. https://doi. org/10.2113/gsecongeo.73.8.1611

4. Ballouard C, Poujol M, Mercadier J, Deloule E, Boulvais P, Baele JM, Cuney M, Cathelineau M (2018) Uranium metallogenesis of the peraluminous leucogranite from the Pontivy-Rostrenen magmatic complex (French Armorican Variscan belt): the result of long-term oxidized hydrothermal alteration during strike-slip deformation. Mineral Deposita 53(5):601-628. https://doi.org/10.1007/ s00126-017-0761-5

5. Cuney M, Emetz A, Mercadier J, Mykchaylov V, Shunko V, Yuslenko A (2012) Uranium deposits associated with Nametasomatism from central Ukraine: a review of some of the major deposits and genetic constraints. Ore Geol Rev 44:82-106. https:// doi.org/10.1016/j.oregeorev.2011.09.007

6. Charoy B, Pollard PJ (1989) Albite-rich, silica-depleted metasomatic rocks at Emuford, Northeast Queensland; mineralogical, geochemical, and fluid inclusion constraints on hydrothermal evolution and tin mineralization. Econ Geol 84(7):1850-1874. https://doi.org/ 10.2113/gsecongeo.84.7.1850

7. Costi HT, Dall'Agnol R, Borges RMK, Minuzzi ORR, Teixeira JT (2002) Tin-bearing sodic episyenites associated with the Proterozoic, A-type Água Boa granite, Pitinga mine, Amazonian Craton, Brazil. Gondwana Res 5(2):435-451. https://doi.org/10. 1016/S1342-937X(05)70734-6

8. Cheilletz A, Giuliani G (1982) Role de la Déformation du Granite dans la Genèse des Episyénites Feldspathiques des Massifs de Lovios-Geres (Galice) et des Zaer (Maroc Central). Mineral Deposita 17(3):387-400. https://doi.org/10.1007/BF00204467

9. Giuliani G (1985) Le gisement de tungstène de Xihuashan (SudJiangxi, Chine): relations granites, altérations deutériqueshydrothermales, minéralisations. Mineral Deposita 20(2):107115. https://doi.org/10.1007/BF00204320

10. López-Moro FJ, Moro MC, Timón SM, Cembranos ML, Cózar J (2013) Constraints regarding gold deposition in episyenites: the Permian episyenites associated with the Villalcampo Shear Zone, central western Spain. Int J Earth Sci 102(3):721-744. https://doi. org/10.1007/s00531-012-0844-6

11. Theodore T, Blair W, Nash T (1987) Geology and gold mineralization of the Gold Basin-Lost Basin mining districts, Mohave County. Arizona US Geol Surv Prof Pap 1361:167

12. McLemore VT (2015) Rare earth elements (REE) deposits in New Mexico: update. N M Geol 37(3):59-69

13. Petersson J, Whitehouse MJ, Eliasson T (2001) Ion microprobe U$\mathrm{Pb}$ dating of hydrothermal xenotime from an episyenite: evidence 
for rift-related reactivation. Chem Geol 175(3):703-712. https:// doi.org/10.1016/S0009-2541(00)00338-7

14. Petersson J, Eliasson T (1997) Mineral evolution and element mobility during episyenitization (dequartzification) and albitization in the postkinematic Bohus granite, southwest Sweden. Lithos 42(1): 123-146. https://doi.org/10.1016/S0024-4937(97)00040-6

15. Ague JJ (2011) Extreme channelization of fluid and the problem of element mobility during Barrovian metamorphism. Am Mineral 96(2-3):333-352. https://doi.org/10.2138/am.2011.3582

16. Petersson J, Stephens MB, Mattsson H, Möller C (2012) Albitization and quartz dissolution in Paleoproterozoic metagranite, central Sweden - implications for the disposal of spent nuclear fuel in a deep geological repository. Lithos 148(Supplement C):10-26. https://doi.org/10.1016/j.lithos.2012. 06.001

17. Suikkanen E, Rämö OT (2017) Metasomatic alkali-feldspar syenites (episyenites) of the Proterozoic Suomenniemi rapakivi granite complex, southeastern Finland. Lithos 294-295(Supplement C):119. https://doi.org/10.1016/j.lithos.2017.09.017

18. Recio C, Fallick AE, Ugidos JM, Stephens WE (1997) Characterization of multiple fluid-granite interaction processes in the episyenites of Avila-Béjar, Central Iberian Massif, Spain. Chem Geol 143(3):127-144. https://doi.org/10.1016/S0009-2541(97) 00106-X

19. Boulvais P, Ruffet G, Cornichet J, Mermet M (2007) Cretaceous albitization and dequartzification of Hercynian peraluminous granite in the Salvezines Massif (French Pyrénées). Lithos 93(1):89106. https://doi.org/10.1016/j.lithos.2006.05.001

20. Streckeisen A (1976) To each plutonic rock its proper name. Earth Sci Rev 12(1):1-33. https://doi.org/10.1016/0012-8252(76)90052-

21. Rossi M, Rolland Y, Vidal O, Cox SF (2005) Geochemical variations and element transfer during shear-zone development and related episyenites at middle crust depths: insights from the Mont Blanc granite (French - Italian Alps). Geol Soc Lond, Spec Publ 245(1):373. https://doi.org/10.1144/GSL.SP.2005.245.01.18

22. Jaques L, Noronha F, Liewig N, Bobos I (2016) Paleofluids circulation associated with the Gerês late-orogenic granitic massif, northern Portugal. Chem Erde Geochem 76(4):659-676. https://doi.org/ 10.1016/j.chemer.2016.09.006

23. Pennacchioni G, Ceccato A, Fioretti AM, Mazzoli C, Zorzi F, Ferretti P (2016) Episyenites in meta-granitoids of the Tauern Window (Eastern Alps): unpredictable? J Geodyn 101:73-87. https://doi.org/10.1016/j.jog.2016.04.001

24. Hecht L, Thuro K, Plinninger R, Cuney M (1999) Mineralogical and geochemical characteristics of hydrothermal alteration and episyenitization in the Königshain granites, northern Bohemian Massif, Germany. Int J Earth Sci 88(2):236-252. https://doi.org/ $10.1007 / \mathrm{s} 005310050262$

25. Nishimoto S, Yoshida H, Asahara Y, Tsuruta T, Ishibashi M, Katsuta N (2014) Episyenite formation in the Toki granite, central Japan. Contrib Mineral Petrol 167(1):960-971. https://doi.org/10. 1007/s00410-013-0960-8

26. Newton RC, Manning CE (2008) Solubility of corundum in the system $\mathrm{A} 12 \mathrm{O} 3-\mathrm{SiO} 2-\mathrm{H} 2 \mathrm{O}-\mathrm{NaCl}$ at $800{ }^{\circ} \mathrm{C}$ and $10 \mathrm{kbar}$. Chem Geol 249(3):250-261. https://doi.org/10.1016/j.chemgeo.2008.01. 002

27. Lobato LM, Fyfe WS (1990) Metamorphism, metasomatism, and mineralization at Lagoa Real, Bahia, Brazil. Econ Geol 85(5):968989. https://doi.org/10.2113/gsecongeo.85.5.968

28. Leloup PH, Ricard Y, Battaglia J, Lacassin R (1999) Shear heating in continental strike-slip shear zones: model and field examples. Geophys J Int 136(1):19-40. https://doi.org/10.1046/j.1365-246X. 1999.00683.x

29. Engvik AK, Ihlen PM, Austrheim H (2014) Characterisation of Nametasomatism in the Sveconorwegian Bamble sector of South
Norway. Geosci Front 5(5):659-672. https://doi.org/10.1016/j.gsf. 2014.03.008

30. Patrier P, Beaufort D, Bril H, Bonhomme M, Fouillac AM, Aumatre R (1997) Alteration-mineralization at the Bernardan U deposit (Western Marche, France); the contribution of alteration petrology and crystal chemistry of secondary phases to a new genetic model. Econ Geol 92(4):448-467. https://doi.org/10.2113/gsecongeo.92.4. 448

31. Walther JV (2001) Experimental determination and analysis of the solubility of corundum in 0.1 and $0.5 \mathrm{~m} \mathrm{NaCl}$ solutions between 400 and $600^{\circ} \mathrm{C}$ from 0.5 to 2.0 kbar. Geochim Cosmochim Acta 65(17):2843-2851. https://doi.org/10.1016/S0016-7037(01)006445

32. González-Casado JM, Caballero JM, Casquet C, Galindo C, Tornos F (1996) Palaeostress and geotectonic interpretation of the Alpine Cycle onset in the Sierra del Guadarrama (eastern Iberian Central System), based on evidence from episyenites. Tectonophysics 262(1):213-229. https://doi.org/10.1016/0040-1951(96)00004-2

33. René M (2017) Alteration of granitoids and crystalline rocks and uranium mineralisation in the Bor pluton area, Bohemian Massif, Czech Republic. Ore Geol Rev 81:188-200. https://doi.org/10. 1016/j.oregeorev.2016.09.033

34. Melcher F, Prochaska W, Raith JG, Saini-Eidukat B (1996) The metamorphosed molybdenum vein-type deposit of the Alpeinerscharte, Tyrol (Austria) and its relation to Variscan granitoids. Mineral Deposita 31(4):277-289. https://doi.org/10.1007/ BF02280792

35. Witt WK (1988) Evolution of high-temperature hydrothermal fluids associated with greisenization and feldspathic alteration of a tinmineralized granite, northeast Queensland. Econ Geol 83(2):310 334. https://doi.org/10.2113/gsecongeo.83.2.310

36. Kinnaird JA, Bowden P, Ixer RA, Odling NWA (1985) Mineralogy, geochemistry and mineralization of the Ririwai complex, northern Nigeria. J Afr Earth Sci (1983) 3(1):185-222. https://doi.org/10. 1016/0899-5362(85)90036-3

37. Rankin AH, Treloar PJ, Lawrence DM, Holliday J, Harbidge P (2013) The geology and mineralogy of the Loulo Mining District, Mali, West Africa: evidence for two distinct styles of orogenic gold mineralization. Econ Geol 108(2):199-227. https://doi.org/10. 2113/econgeo.108.2.199

38. Nijland TG, Harlov DE, Andersen T (2014) The Bamble sector, South Norway: a review. Geosci Front 5(5):635-658. https://doi. org/10.1016/j.gsf.2014.04.008

39. Le Bas MJ (1987) Nephelinites and carbonatites. Geol Soc Lond, Spec Publ 30(1):53-83. https://doi.org/10.1144/gsl.sp.1987.030. 01.05

40. Elliott HAL, Wall F, Chakhmouradian AR, Siegfried PR, Dahlgren S, Weatherley S, Finch AA, Marks MAW, Dowman E, Deady E (2018) Fenites associated with carbonatite complexes: a review. Ore Geol Rev 93:38-59. https://doi.org/10.1016/j.oregeorev.2017.12. 003

41. Rubie DC (1982) Mass transfer and volume change during alkali metasomatism at Kisingiri, Western Kenya. Lithos 15(2):99-109. https://doi.org/10.1016/0024-4937(82)90003-2

42. Poujol M, Boulvais P, Kosler J (2010) Regional-scale cretaceous albitization in the Pyrenees: evidence from in situ $\mathrm{U}-\mathrm{Th}-\mathrm{Pb}$ dating of monazite, titanite and zircon. J Geol Soc 167(4):751-767. https:// doi.org/10.1144/0016-76492009-144

43. Lespinasse M, Cathelineau M (1990) Fluid percolations in a fault zone: a study of fluid inclusion planes in the St Sylvestre granite, northwest Massif Central, France. Tectonophysics 184(2):173-187. https://doi.org/10.1016/0040-1951(90)90052-A

44. Petersson J, Fallick AE, Broman C, Eliasson T (2014) Imprints of multiple fluid regimes on episyenites in the Bohus granite, Sweden. Lithos 196-197:99-114. https://doi.org/10.1016/j.lithos.2014.02. 025 
45. López-Moro FJ, Romer RL, Rhede D, Fernández A, TimónSánchez SM, Moro MC (2018) Early uranium mobilization in late Variscan strike-slip shear zones affecting leucogranites of central western Spain. J Iber Geol 45:223-243. https://doi.org/10.1007/ s41513-018-0091-1

46. Caballero JM (1993) Las episienitas de la Sierra de Guadarrama: Un caso singular de alteración hidrotermal de edad post-Hercínina. Universidad Complutense Madrid, Doctoral thesis

47. Scaillet S, Cheilletz A, Cuney M, Farrar E, Archibald DA (1996) Cooling pattern and mineralization history of the Saint Sylvestre and western Marche leucogranite pluton, French Massif Central: I. 40Ar/39Ar isotopic constraints. Geochim Cosmochim Acta 60(23): 4653-4671. https://doi.org/10.1016/S0016-7037(96)00291-8

48. Putnis A (2002) Mineral replacement reactions: from macroscopic observations to microscopic mechanisms. Mineral Mag 66(5):689708. https://doi.org/10.1180/0026461026650056

49. Hövelmann J, Putnis A, Geisler T, Schmidt BC, Golla-Schindler U (2010) The replacement of plagioclase feldspars by albite: observations from hydrothermal experiments. Contrib Mineral Petrol 159(1):43-59. https://doi.org/10.1007/s00410-009-0415-4

50. Plümper O, Botan A, Los C, Liu Y, Malthe-Sørenssen A, Jamtveit B (2017) Fluid-driven metamorphism of the continental crust governed by nanoscale fluid flow. Nat Geosci 10:685-690. https://doi.org/10.1038/ngeo3009

51. Parsons I (1978) Feldspars and fluids in cooling plutons. Mineral Mag 42(321):1-17

52. Putnis A (2015) Transient porosity resulting from fluid-mineral interaction and its consequences. Rev Mineral Geochem 80(1):123. https://doi.org/10.2138/rmg.2015.80.01

53. Costi HT, Dall'Agnol R, Pichavant M, Rämö OT (2009) The peralkaline tin-mineralized Madeira cryolite albite-rich granite of Pitinga, Amazonian craton, Brazil: petrography, mineralogy and crystallization processes. Can Mineral 47(6):1301-1327. https:// doi.org/10.3749/canmin.47.6.1301

54. Gresens RL (1967) Composition-volume relationships of metasomatism. Chem Geol 2:47-65. https://doi.org/10.1016/00092541(67)90004-6

55. Grant JA (1986) The isocon diagram; a simple solution to Gresens' equation for metasomatic alteration. Econ Geol 81(8):1976-1982. https://doi.org/10.2113/gsecongeo.81.8.1976

56. Parneix JC, Beaufort D, Dudoignon P, Meunier A (1985) Biotite chloritization process in hydrothermally altered granites. Chem Geol 51(1):89-101. https://doi.org/10.1016/0009-2541(85)900890

57. Leroy JL, Turpin L (1988) REE, Th and U behaviour during hydrothermal and supergene processes in a granitic environment. Chem Geol 68(3):239-251. https://doi.org/10.1016/00092541(88)90024-1

58. Turpin L, Leroy JL, Sheppard SMF (1990) Isotopic systematics (O, $\mathrm{H}, \mathrm{C}, \mathrm{Sr}, \mathrm{Nd}$ ) of superimposed barren and U-bearing hydrothermal systems in a Hercynian granite, Massif Central, France. Chem Geol 88(1):85-98. https://doi.org/10.1016/0009-2541(90)90105-G

59. Borges RMK, Villas RNN, Fuzikawa K, Dall'Agnol R, Pimenta MA (2009) Phase separation, fluid mixing, and origin of the greisens and potassic episyenite associated with the Água Boa pluton, Pitinga tin province, Amazonian Craton, Brazil. J S Am Earth Sci 27(2):161-183. https://doi.org/10.1016/j.jsames.2008.11.006

60. Fossen H, Cavalcante GCG (2017) Shear zones - a review. Earth Sci Rev 171:434-455. https://doi.org/10.1016/j.earscirev.2017.05. 002

61. Rowland JV, Sibson RH (2004) Structural controls on hydrothermal flow in a segmented rift system, Taupo Volcanic Zone, New Zealand. Geofluids 4(4):259-283. https://doi.org/10.1111/j.14688123.2004.00091.x
62. Sibson RH (1994) Crustal stress, faulting and fluid flow. Geol Soc Lond, Spec Publ 78(1):69-84. https://doi.org/10.1144/GSL.SP. 1994.078.01.07

63. Tullis J, Yund RA (1991) Diffusion creep in feldspar aggregates: experimental evidence. J Struct Geol 13(9):987-1000. https://doi. org/10.1016/0191-8141(91)90051-J

64. Mukai H, Austrheim H, Putnis CV, Putnis A (2014) Textural evolution of plagioclase feldspar across a shear zone: implications for deformation mechanism and rock strength. J Petrol 55(8):14571477. https://doi.org/10.1093/petrology/egu030

65. Cox SF, Etheridge MA, Wall VJ (1987) The role of fluids in syntectonic mass transport, and the localization of metamorphic vein-type ore deposists. Ore Geol Rev 2(1):65-86. https://doi.org/ 10.1016/0169-1368(87)90024-2

66. McCaig AM (1988) Deep fluid circulation in fault zones. Geology 16(10):867-870. https://doi.org/10.1130/0091-7613(1988) $016<0867$ :DFCIFZ $>2.3 . \mathrm{CO} ; 2$

67. Cox SF (2002) Fluid flow in mid-to deep crustal shear systems: experimental constraints, observations on exhumed high fluid flux shear systems, and implications for seismogenic processes. Earth, Planets and Space 54(11):1121-1125. https://doi.org/10.1186/ BF03353312

68. Fusseis F, Regenauer-Lieb K, Liu J, Hough RM, De Carlo F (2009) Creep cavitation can establish a dynamic granular fluid pump in ductile shear zones. Nature 459:974-977. https://doi.org/10.1038/ nature 08051

69. Cox SF, Etheridge MA (1989) Coupled grain-scale dilatancy and mass transfer during deformation at high fluid pressures: examples from Mount Lyell, Tasmania. J Struct Geol 11(1):147-162. https:// doi.org/10.1016/0191-8141(89)90040-0

70. Guermani A, Pennacchioni G (1998) Brittle precursors of plastic deformation in a granite: an example from the Mont Blanc massif (Helvetic, western Alps). J Struct Geol 20(2):135-148. https://doi. org/10.1016/S0191-8141(97)00080-1

71. Fournier RO (1999) Hydrothermal processes related to movement of fluid from plastic into brittle rock in the magmatic-epithermal environment. Econ Geol 94(8):1193-1211

72. Shmulovich KI, Yardley BWD, Graham CM (2006) Solubility of quartz in crustal fluids: experiments and general equations for salt solutions and $\mathrm{H} 2 \mathrm{O}-\mathrm{CO} 2$ mixtures at $400-800^{\circ} \mathrm{C}$ and $0.1-0.9$. GPa. 6(2):154-167. https://doi.org/10.1111/j.1468-8123.2006.00140.x

73. Akinfiev NN, Diamond LW (2009) A simple predictive model of quartz solubility in water-salt-CO2 systems at temperatures up to $1000^{\circ} \mathrm{C}$ and pressures up to $1000 \mathrm{MPa}$. Geochim Cosmochim Acta 73(6):1597-1608. https://doi.org/10.1016/j.gca.2008.12.011

74. Fournier RO (1983) A method of calculating quartz solubilities in aqueous sodium chloride solutions. Geochim Cosmochim Acta 47(3):579-586

75. Fournier RO, Potter RW (1982) An equation correlating the solubility of quartz in water from $25^{\circ}$ to $900^{\circ} \mathrm{C}$ at pressures up to 10,000 bars. Geochim Cosmochim Acta 46(10):1969-1973. https://doi. org/10.1016/0016-7037(82)90135-1

76. Wagner W, Cooper JR, Dittmann A, Kijima J, Kretzschmar HJ, Kruse A, Mareš R, Oguchi K, Sato H, Stöcker I, Šifner O, Takaishi Y, Tanishita I, Trübenbach J, Willkommen T (2000) The IAPWS industrial formulation 1997 for the thermodynamic properties of water and steam. J Eng Gas Turbines Power 122(1):150 184. https://doi.org/10.1115/1.483186

77. Bischoff JL, Pitzer KS (1989) Liquid-vapor relations for the system $\mathrm{NaCl}-\mathrm{H}_{2} \mathrm{O}$ : summary of the PT-x surface from $300^{\circ}$ to $500^{\circ} \mathrm{C}$. Am J Sci 289(3):217-248. https://doi.org/10.2475/ajs.289.3.217

78. Hovey JK, Pitzer KS, Tanger JC, Bischoff JL, Rosenbauer RJ (1990) Vapor-liquid phase equilibria of potassium chloride-water mixtures: equation-of-state representation for potassium chloridewater and sodium chloride-water. J Phys Chem 94(3):1175-1179. https://doi.org/10.1021/j100366a032 
79. Kaur P, Chaudhri N, Hofmann AW, Raczek I, Okrusch M, Skora S, Baumgartner LP (2012) Two-stage, extreme Albitization of A-type granites from Rajasthan, NW India. J Petrol 53(5):919-948. https:// doi.org/10.1093/petrology/egs003

80. Connolly JAD (1997) Mid-crustal focused fluid movement: thermal consequences and silica transport. In: Jamtveit B, Yardley BWD (eds) Fluid flow and transport in rocks: mechanisms and effects. Springer Netherlands, Dordrecht, pp 235-250. https://doi. org/10.1007/978-94-009-1533-6_14

81. Hedenquist JW, Lowenstern JB (1994) The role of magmas in the formation of hydrothermal ore deposits. Nature 370:519-527. https://doi.org/10.1038/370519a0

82. Cathles LM, Erendi AHJ, Barrie T (1997) How long can a hydrothermal system be sustained by a single intrusive event? Econ Geol 92(7-8):766-771. https://doi.org/10.2113/gsecongeo.92.7-8.766

83. Fallourd S, Poujol M, Boulvais P, Paquette J-L, de Saint Blanquat M, Rémy P (2014) In situ LA-ICP-MS U-Pb titanite dating of NaCa metasomatism in orogenic belts: the North Pyrenean example. Int J Earth Sci 103(3):667-682. https://doi.org/10.1007/s00531013-0978-1

84. Golberg JM, Leyreloup AF (1990) High temperature-low pressure Cretaceous metamorphism related to crustal thinning (Eastern North Pyrenean Zone, France). Contrib Mineral Petrol 104(2): 194-207. https://doi.org/10.1007/BF00306443

85. Haines S, Lynch E, Mulch A, Valley JW, van der Pluijm B (2016) Meteoric fluid infiltration in crustal-scale normal fault systems as indicated by $\delta 18 \mathrm{O}$ and $\delta 2 \mathrm{H}$ geochemistry and $40 \mathrm{Ar} / 39 \mathrm{Ar}$ dating of neoformed clays in brittle fault rocks. Lithosphere 8(6):587-600. https://doi.org/10.1130/L483.1

86. Lobato LM, Pimentel MM, Cruz SCP, Machado N, Noce CM, Alkmim FF (2015) U-Pb geochronology of the Lagoa Real uranium district, Brazil: implications for the age of the uranium mineralization. J S Am Earth Sci 58:129-140. https://doi.org/10. 1016/j.jsames.2014.12.005

87. Yardley BWD, Cleverley JS (2015) The role of metamorphic fluids in the formation of ore deposits. Geol Soc Lond, Spec Publ 393(1): 117-134. https://doi.org/10.1144/SP393.5

88. Castorina F, Masi U, Padalino G, Palomba M (2006) Constraints from geochemistry and $\mathrm{Sr}-\mathrm{Nd}$ isotopes for the origin of albitite deposits from Central Sardinia (Italy). Mineral Deposita 41(4): 323-338. https://doi.org/10.1007/s00126-006-0049-7

89. Eglinger A, Tarantola A, Durand C, Ferraina C, Vanderhaeghe O, André-Mayer A-S, Paquette J-L, Deloule E (2014) Uranium mobilization by fluids associated with $\mathrm{Ca}-\mathrm{Na}$ metasomatism: a $\mathrm{P}-\mathrm{T}-\mathrm{t}$ record of fluid-rock interactions during Pan-African metamorphism (Western Zambian Copperbelt). Chem Geol 386:218-237. https://doi.org/10.1016/j.chemgeo.2014.07.028

90. Timofeev A, Migdisov AA, Williams-Jones AE, Roback R, Nelson AT, Xu H (2018) Uranium transport in acidic brines under reducing conditions. Nat Commun 9(1):1469. https://doi.org/10.1038/ s41467-018-03564-7

91. Tartèse R, Boulvais P, Poujol M, Gloaguen E, Cuney M (2013) Uranium mobilization from the Variscan Questembert syntectonic granite during fluid-rock interaction at depth. Econ Geol 108(2): 379-386. https://doi.org/10.2113/econgeo.108.2.379

92. Béziat D, Dubois M, Debat P, Nikiéma S, Salvi S, Tollon F (2008) Gold metallogeny in the Birimian craton of Burkina Faso (West Africa). J Afr Earth Sci 50(2):215-233. https://doi.org/10.1016/j. jafrearsci.2007.09.017

Publisher's Note Springer Nature remains neutral with regard to jurisdictional claims in published maps and institutional affiliations. 